\title{
Forestry in Canada: Yesterday - today - tomorrow La foresterie au Canada: hier - aujourd'hui - demain
}

\author{
Sault Ste-Marie, Ontario \\ October 3-October 6, 1983
}

The Forestry Chronicle

Volume 59, Number 6. December 1983

Annual Meeting Supplement

\begin{abstract}
The Forestry Chronicle
Volume 59, Numéro 6, décembre 1983

Supplément de l'Assemblée Annuelle
\end{abstract}

\section{President's Report 1983}

Welcome to the 75th Annual Meeting of the Canadian Institute of Forestry/Institut Forestier du Canada. Today we have more than 280 members, spouses and guests attending our meeting; 75 years ago, on March 12, 1908, nine foresters met at the Montreal Board of Trade to discuss the organization of a "Dominion-wide society of technically trained foresters and officials". A constitution was drawn up and the objectives of the organization. The Canadian Society of Forest Engineers, were to discuss the "technical subjects relating to the theory and practice of forestry, and to cultivate an esprit de corps among members of the profession"

In view of the historic significance of this meeting, it is appropriate that it is being held in Sault Ste. Marie. For thousands of years this area has been home to native people who called this location "Bawating" - meaning shallow water rushing over stones". In the early 1600's Etienne Burlé paddled up the St. Mary's River and he named this location, between Lakes Huron and Superior, Saut du Gaston. Saut is an old French name for falls, while Gaston was the brother of Louis XIII of France. The name Saut was shown on a map prepared by Samuel de Champlain in 1632; it is the oldest geographical place name in Ontario, and the ninth oldest in Canada.

In 1950 the Annual Meeting of the Canadian Society of Forest Engineers was held in Sault Ste. Marie. The meeting was held at the Windsor Hotel and was attended by 167 members and 7 visitors. The theme was "Applied Silviculture", The chairman of the Annual Meeting Committee was the late C.A. Rowe, members were listed as Ross Hyslop and the late S.T.B. Losee. We are pleased that Ross is in attendance at this meeting.

The Annual Meeting is the occasion for the President to outline the activities and accomplishments of the past year. I believe that it has been reasonably successful, in spite of the fact that the overall economic situation has been poor and we are living through the worst of economic times since the 1930 's. One year ago Bob Bourchier was appointed as Executive Director with the responsibility of ensuring that our National Office operates in an efficient and effective manner. I believe that this objective has been met and that our financial and membership records and files are now in good shape and that Head Office is providing the service which you as

\section{Rapport du Président 1983}

Je vous souhaite la bienvenue à la soixante-quinzième $\left(75^{\mathrm{e}}\right)$ réunion annuelle de I'Institut forestier du Canada (Canadian Institute of Forestry). Aujourd'hui, plus de 280 membres, conjoints et invités participent à la réunion; il y a 75 ans, le 12 mars 1908, neuf forestiers se sont réunis à la Chambre de commerce de Montréal pour discuter la création d'un organisation nationale qui comprendrait des forestiers et des fonctionnaires formés dans ce domaine technique. Une constitution a été préparée. L'organisation, la société canadienne des forestiers (The Canadian Society of Forest Engineers), avait pour but de discuter les "sujets techniques qui touchant la théorie et la mise en pratique du domaine forestier et de créer un esprit de corps parmi les membres de la profession."

Étant donné l'importance historique de cette réunion, il est opportun que la réunion d'aujourd'hui ait lieu à Sault SteMarie. Pendant des milliers d'années, cette région a été habitée par des autochtones qui appelaient cet endroit "Bawating" qui signifie "l'eau peu profonde qui jaillit parmi les roches." Au début des années 1600 s, Etienne Brulé a remonté la rivière St. Mary en pagayant et a nommé cette région, entre les lacs Huron et Supérieur, Saut du Gaston. Saut est l'ancien nom français pour des chutes, et Gaston était le frère de Louis XIII de France. Le nom Saut a paru sur une carte géographique préparée par Samuel de Champlain en 1632; c'est la région géographique la plus vieille de l'Ontario et la neuvième au Canada.

En 1950, la réunion annuelle de la société canadienne des forestiers (Canadian Society of Foresters) a eu lieu à Sault Ste-Marie à I'hôtel Windsor; 167 membres et 7 invités y ont participé. Le thème était "La sylviculture appliquée". Le président du Comité de la réunion annuelle était M. C.A. Rowe (défunt) et les membres étaient M. Ross Hyslop et M. S.T.B. Losee (défunt). II nous fait plaisir de voir Ross parmi nous à cette réunion.

A l'occasion de la réunion annuelle, le Président souligne les activités et les projets réalisés durant cette dernière année. Je crois que l'année a été assez fructueuse, malgré la situation économique la plus grave depuis les années 1930s. II y a un an M. Bob Bourchier a été nommé directeur administratif ayant la responsabilité d'assurer que le bureau national fonctionne de façon efficace. Je crois que nous avons atteint ce but et les dossiers financiers et les dossiers des membres 
members should expect. I am pleased to report that the Board of Directors has approved the formation of a new Section to be centred in the Williams Lake area of central British Columbia.

A major activity during the past year has been the establishment of a Forest Science and Technology Board. This Board, under the chairmanship of a Vice-President, will be meeting later this week and has the responsibility of stimulating scientific and technical activity within the Institute. I am grateful that Messrs. Carrow, Honer, Lafond and Squires have agreed to serve on the Board.

In accordance with a clear mandate given by your Board of Directors last year, we have continued to cooperate and communicate with other forestry organizations concerned with promoting improved forest management in Canada. Working with the four professional associations through the Canadian Federation of Professional Foresters Associations, we have prepared a brief on the use of herbicides in forestry which will be submitted to the Federal Minister of Environment. The Institute is now preparing a brief on forestry for submission to the Royal Commission on Economic Union and Development Prospects for Canada, commonly referred to as the Macdonald Royal Commission. This will be followed by the preparation of a second brief to be prepared by the Canadian Federation of Professional Foresters Associations. In accordance with a resolution passed at the 1982 Annual Meeting. the Institute increased its participation in National Forest Week, 1983. I represented the CIF/IFC at ceremonies proclaiming Smokey Lake, Alberta, as Forestry Capital of Canada. Projects undertaken by our Sections during this week included tree planting ceremonies, preparation of newspaper articles, displays in shopping malls, school visitations and poster contests. The Skeena Section, formed in 1982, sponsored a Forestry Fair at Smithers which included information booths, displays, demonstrations of forestry equipment and a loggers sport competition. Finally, I anticipate that the CIF/IFC and CFA will be signing a letter of understanding in the near future. During the year the Institute was a co-sponsor of two important conferences, Acid Rain and Forest Resources and the Sixth North American Forest Soils Conference.

At the 1982 Annual Meeting, 15 resolutions were passed. The Executive Committee has taken action on all of these which involved their distribution to the Prime Minister, to Provincial Premiers, to Federal and Provincial Ministers responsible for forestry and industrial development and to the Canadian Council of Resource and Environment Ministers. It should be noted that the Prime Minister rejected proposals for the establishment of a special task force or subcommittee of the Standing Committee on Fisheries and Forestry and for the establishment of a Canadian Department of Renewable Resources. With the exception of the Canadian Council of Resource and Environment Ministers, from whom we have not heard, response has been good. Many of the replies to the resolutions have been published in The Forestry Chronicle. The Executive Committee has taken action with respect to several internally directed resolutions. An International Forestry Working Group has been established and is holding its first meeting later this week (82.7). We have introduced a regular column on forest policy in The Forestry Chronicle (82.14). The problem of use of prime forest land for submarginal agricultural use has been a matter of continuing concern by BC Sections who have been involved for some time in forest land alienation issues. BC Sections will assess and react to local situations when the problem of alientation of forest land for sub-marginal agriculture is occurring (82.12). Specific action concerning the establishment of a special Task Force to develop a precise and constructive tax amendment proposal was deferred pending completion of a Canadian Forestry Association study on current forest taxa- sont maintenant bien organisés. Le bureau s'occupe de tout ce qui touche les membres. II me fait plaisir d'annoncer que le Conseil d'administration a sanctionné la création d'une nouvelle Section qui sera située dans la région de Williams Lake en Colombie-Britannique.

Une des activités les plus importantes durant cette dernière année a été l'établissement d'un conseil des sciences et de la technologie des forêts (Forest Science and Technology Board). Ce conseil, sous la présidence d'un vice-président, se réunira plus tard cette semaine et aura pour but d'encourager les activités scientifiques et techniques au sein de l'Institut. Messieurs Carrow, Honer, Lafond et Squires ont consenti à faire partie du conseil.

Conformément au mandat précis du Conseil d'administration livré l'année dernière, nous avons continué de coopérer et de communiquer avec les autres organisations du domaine forestier qui sont responsables d'encourager l'amélioration de la gestion forestière au Canada. Avec la participation de quatre associations professionnelles par l'entremise de la fédération canadienne des associations de forestiers (Canadian Federation of Professional Foresters Associations), nous avons préparé une soumission sur l'utilisation des herbicides dans les forêts qui sera soumise au Ministre fédéral de l'Environnement. L'Institut est en voie de préparer une soumission sur les forêts qui sera présentée à la Commission royale sur l'union économique et les perspectives de développement du Canada. Par la suite, une deuxième soumission sera préparée par la fédération canadienne des associations de forestiers (Canadian Federation of Professional Foresters Associations). Conformément à une résolution adoptée à la réunion annuelle de 1982, l'Institut a augmenté sa participation à la semaine nationale des forêts 1983. J'ai représenté la CIF/IFC aux cérémonies qui proclamaient Smokey Lake en Alberta la capitale des forêts canadiennes. Durant cette semaine-là les Sections ont participé à plusieurs activités: des cérémonies pour semer de nouveaux arbres; la préparation d'articles pour les journaux; des visites aux écoles; et des concours de dessin. La Section Skeena, établie en 1982, a organisé une exposition forestière à Smithers qui comprenait des bureaux de renseignements, des expositions, des démonstrations des équipements utilisés dans le domaine et des concours de "logging". En dernier lieu, je prévois que la CIF/IFC et l'Association forestière canadienne parviendront à un accord d'ici quelques temps. Durant l'année l'Institut a participé à l'organisation de deux colloques importants: la pluie acide et les forêts; et, le Sixth North American Forest Soils Conference.

A l'occasion de la réunion annuelle de 1982, quinze résolutions ont été adoptées. Le Comité exécutif a pris des mesures pour s'occuper de toutes les résolutions qui devaient être envoyées au Premier ministre, aux premiers ministres provinciaux responsables du développement forestier et industriel et au Conseil canadien des ministres des richesses et de l'environnement. II faudrait souligner que le Premier ministre a rejeté les propositions d'établir un groupe de travail spécial ou un sous-comité du Comité permanent des pêches et des forêts et d'établir un ministère canadien des richesses renouvelables. A l'exception du Conseil canadien des ministres des richesses et de l'environnement, qui n'a pas répondu, nous avons reçu beaucoup d'autres réponses. Plusieurs réponses ont été publiées dans le "Forestry Chronicle". Le Comité exécutif a aussi pris des mesures quant à plusieurs résolutions qui touchaient l'Institut elle-même. Un groupe de travail international des forêts a été établi et se réunira pour la première fois plus tard cette semaine (82.7). Nous avons inclus un article régulier concernant les politiques du domaine forestier dans le "Forestry Chronicle" (82.14). Les problèmes de l'utilisation des forêts pour la culture des terres pauvres sont étudiés continuellement par les Sections de la Colombie- 
tion policies. Subsequent to the completion of this study, the resolution was referred to the Working Group on Economics and Policy (82.5). As reported earlier, the CIF/IFC actively participated in National Forest Week 1983 (82.13). Phil Gilbert, 1982 and 1983 Resolutions Committee Chairman, has prepared a statement concerning development, review, approval and use of Annual Meeting resolutions (82.18).

During the past year it has been my pleasure to visit with 13 sections from Vancouver Island to Newfoundland and to participate in ring ceremonies at the Universities of New Brunswick, Toronto and British Columbia. Over the past three years I have visited with 19 of the 23 sections. This has been a most rewarding experience as it has afforded me the opportunity of meeting many of our members. As has been said many times, the strength of our Institute is at the Section level. In the past year most sections have been active and have been involved in a wide array of activities. Some highlights include the Nova Scotia Section Brief to the Royal Commission on Forestry, private land forestry briefs by the Maritime, Southern Ontario and Ottawa Valley Sections, submissions on Ontario land-use planning by the Central Ontario, Algonquin and Lake of the Woods Sections, a joint submission to the Quebec Office of Public Hearings on the Environment by the Orleans and Champlain Sections, the submission of a variety of letters and briefs, often in collaboration with the Association of BC Registered Foresters, by BC Sections, preparation of forest management plan for Victoria YM-YWCA Camp Thunderbird by the Vancouver Island Section, presentation of a brief on the timber resource of Alberta by the Rocky Mountain Section, and the organization of various special meetings and activities and preparation of histories by many sections during our 75 th year.

Your Executive Committee has maintained communications with federal politicians and officials. In February we met with the Honourable John Roberts, then Minister of the Environment, Jacques Gérin, Deputy Minister and Lyle Kristiansen, NDP forestry critic. We are pleased that the Honorable Charles Caccia, newly-appointed Minister of the Environment, is with us today. It is vitally important that we maintain this dialogue. The CIF/IFC has also endorsed the Science Council report "Canada's Threatened Forests".

While I believe we have made good progress over the past year, there are some areas of concern. One of these is membership which declined by 10 per cent in 1981 and 1982 . Fortunately there is currently an indication of growth with an increase of more than 100 members in 1983. It is important that we work with maximum effort to increase membership. Experience has indicated that specific and targeted membership drives can be successful. I am also concerned with the viability of a few of our Sections. Some are relatively inactive and need strengthening.

The first two objectives of our Institute are (a) To improve all aspects of forestry in Canada, and (2) To foster public understanding of forestry, forests and the forest industry. There is no argument about the economic and social importance of our forest resources. Their importance in terms of numbers of jobs, value of manufacturing shipments, amount of tax revenues to federal and provincial governments, amount of exports and role in balance of trade is unquestioned. It is important to note that our forests are renewable. Their benefits can be sustained and even increased in the future, but only if we invest in them. Forest management must become more intensive or our industry will face shortages of economically available timber and ultimately will decline.

Our Institute was founded in 1908 at a time when Canadians were concerned about exploitation of our forests. However, little forest management was practised in the country until the 1950 's. In the past 30 years there has been a dramatic
Britannique évalueront les situations locales et réagiront aux problèmes de l'aliénation des forêts pour l'agriculture des terres pauvres (82.12). L'établissement du groupe de travail spécial pour développer des modifications fiscales précises et concrètes a été remis en attendant le rapport de l'Association forestière canadienne sur les politiques fiscales courantes qui touchent le domaine forestier. Dans l'attente de cette étude, la résolution a été passée au groupe de travail sur l'économie et les politiques (82.5). Comme cela a déjà été souligné, la CIF/IFC a participé activement à la semaine nationale des forêts 1983 (82.12). M. Phil Gilbert, le président du comité des résolutions pour 1982 et 1983, a préparé un rapport au sujet du développement, de la revue, de l'approbation et de l'utilisation des résolutions de la réunion annuelle (82.18).

Pendant cette dernière année, j'ai eu l'occasion de visiter 13 sections de l'île Vancouver à Terre-Neuve et de participer aux cérémonies des joncs à l'université du NouveauBrunswick, de Toronto et de la Colombie-Britannique. Durant les trois dernières années, j'ai visité 19 des 23 sections. Ces visites ont bien valu la peine puisque j'ai pu rencontrer beaucoup de membres. On a souvent dit que la force de l'Institut repose sur les Sections. Pendant 1983, la plupart des sections ont participé à une grande diversité d'activités: une soumission de la Section de la Nouvelle-Écosse présentée à la Commission royale sur les forêts; des soumissions sur les forêts privées préparées par les Sections des maritimes, du sud de l'Ontario et de la vallée de l'Outaouais; des soumissions sur l'aménagement des terres en Ontario préparées par les Sections de l'Ontario central, d'Algonquin et de Lake of the Woods; une soumission collective au Bureau d'audiences publiques sur l'environnement (gouvernement du Québec) a été préparée par les Sections Orléans et Champlain; la remise par les Sections de la Colombie-Britannique d'une diversité de lettres et de soumissions, souvent avec la participation de l'Association of BC Registered Foresters; la préparation d'un programme de gestion forestière pour le camp Thunderbird du YM-YWCA à Victoria par la Section de l'île Vancouver; la présentation d'une soumission sur les ressources de bois en Alberta par la Section Rocky Mountain; I'organisation de plusieurs réunions spéciales et d'activités; et la préparation de l'historique de plusieurs sections pendant notre $75^{\mathrm{e}}$ année.

Le Comité exécutif a continué de communiquer avec les politiciens et les fonctionnaires fédéraux. En février, nous nous sommes réunis avec l'honorable John Roberts, le ministre de l'Environnement à cet époque, M. Jacques Gérin, le sous-ministre et $M$. Lyle Kristiansen, le représentant en matière forestière du NPD. II nous fait plaisir d'accueillir parmi nous aujourd'hui l'honorable Charles Caccia récemment nommé le ministre de l'Environnement. II est essentiel de poursuivre notre dialogue. La CIF/IFC a aussi sanctionnée le rapport "La forêt canadienne en danger" préparé par le Conseil des sciences du Canada.

Bien que nous ayons fait des progrès durant cette dernière année, il reste encore quelques problèmes à résoudre; notamment, le nombre de membres qui a diminué de 10 pour cent en 1981 et 1982 . Heureusement, le nombre de membres a augmenté de 100 en 1983. II faut faire tout notre possible pour augmenter le nombre de membres. L'expérience a démontré que des campagnes spécifiques de recrutement des membres peuvent apporter du succès. Je suis aussi inquiet de la viabilité de quelques Sections: quelques-unes sont inactives et ont besoin d'appui.

Les deux principaux buts de l'Institut sont: a) d'améliorer tous les aspects du domaine forestier au Canada et b) d'encourager le publique à acquérir des connaissances au sujet du domaine forestier, des forêts et de l'industrie forestière. II y a aucun doute que les richesses forestières jouent un rôle 
improvement in forest management programs and efforts by provincial governments and industry are applauded. However, we cannot afford to be complacent. Annually 750000 hectares of forest are harvested across the country, but less than one-quarter of it is planted or seeded. Approximately 200000 hectares are annually lost from commercial forest production through failure to regenerate. Through past neglect as many as 1 in 9 hectares are not now stocked with commercial forest.

The Institute continues to be concerned with the inadequacy of forest protection programs. We believe that forest protection is a part of forest management and investments in forest renewal are of little value unless the forests that are established are protected against fire, insects, diseases and weeds. Losses from fire, insects and diseases are reported to equal two thirds of our harvest. In the 1980's we are witnessing enormous losses from fire, from the spruce budworm and the mountain pine beetle. These losses must be reduced if maximum benefits are to be realized from our forests.

In 1983 the Institute developed a policy statement on the use of chemical pesticides in forestry. We are particularly concerned that implementation of some currently available techniques for reducing losses and for restocking forest land are currently being constrained by political response to environmentalists and other public interest groups. In particular, I am thinking about use restrictions on currently registered insecticides and herbicides. While the Institute strongly supports continuing research on silvicultural and biological control of forest pests, we recognize that chemical pesticides will have to be used to achieve forest management objectives. We hope, however, that our reliance on them will lessen in the future. Accordingly, we support responsible use of registered chemical pesticides in forest practise. We also note that Canadian forestry Ministers have recently recognized the need for the use of both insecticides and herbicides in forest management. Reports by the Newfoundland Medical Society, the Ontario Medical Association, the Inverness-Victoria (Nova Scotia) Medical Society and more recently by Nova Scotia Judge Nunn, strongly support the view that registered chemicals can be used safely.

Another area of concern is the continuing trend on the part of certain provincial governments to withdraw commercial forest land for single use purposes such as parks, wilderness areas, ecological reserves, hydro-electric projects, agriculture land, transportation, communication and transmission corridors, seismic lines and residential, recreational and industrial land use. These decisions have led to a significant decrease in the annual allowable cut in some provinces. The $\mathrm{CIF} / \mathrm{IFC}$ intends to analyze this situation in detail over the next year.

Education and research are two more areas of concern. Funding for forestry faculties is declining and teaching staff is inadequately supported. We expect there will be a need for increased numbers of foresters and technicians during the next 10 to 25 years and our forestry educational institutions must be able to meet this demand. Canadian forest research has long been neglected and is in a rather deplorable state. The major national forestry research agency, the Canadian Forestry Service, has been continually cut back over the past 15 years and the numbers of person years available to research has declined by more than 50 per cent. Some provinces have recently announced plans to terminate or severely curtail their forest research programs. These declines have occurred at a time when there are increased demands for more information and technology for forest management. The current research effort is inadequately coordinated, although we support recent initiatives by the Canadian Forestry Service to establish a Canadian Forest Research économique et social important: le nombre d'emplois créé; le nombre d'expéditions manufacturières; les recettes fiscales remises au gouvernement fédéral et aux gouvernements provinciaux; les montants d'exportation et le rôle dans la balance du commerce sont incontestés. II faut souligné que les forêts peuvent être maintenues et même augmentées dans l'avenir, mais seulement si on investit dans les forêts. La gestion forestière doit s'améliorer considérablement sinon l'industrie fera face à une insuffisance de bois et diminuera par conséquent.

L'Institut a été établi en 1908 à l'époque où les Canadiens ne s'occupaient que d'exploiter les forêts. Cependant, il y a eu peu de gestion forestière avant les années 1950s. Durant les 30 dernières années, les programmes de gestion forestière ont amélioré considérablement. Les gouvernements provinciaux et l'industrie ont joué un rôle important. Toutefois, ce n'est pas suffisant. Chaque année 750000 hectares de forêts sont récoltés à travers le pays, mais moins d'un quart est planté ou semé de nouveau. Environ 200000 hectares sont perdus chaque année à la production commerciale forestière parce que les arbres ne sont pas remplacés. En raison de la négligence, 1 hectare sur 9 n'est pas remplacé par des forêts commerciales.

L'Institut continue d'être inquiet du manque de programmes pour la protection des forêts. Nous croyons que la protection des forêts fait partie intégrante de la gestion forestière et que les investissements pour le rempalcement des forêts auront peu de valeur si les forêts ne sont pas protégées du feu, des insectes, des maladies et des mauvaises herbes. Les pertes résultant des feux, des insectes et des maladies comptent deux-tiers de la récolte. Durant les années 1980s, nous faisons face à de grosses pertes causées par le feu, par la tordeuse des bourgeons de l'épinette et le "mountain pine beetle". Ces pertes doivent être réduites pour que les bénéfices maximaux tirés de nos forêts soient atteints.

En 1983, I'Institut a développé une politique sur l'utilisation des produits chimiques dans le domaine forestier. Nous sommes notamment inquiets que la mise en vigueur des techniques actuelles disponibles pour réduire les pertes et recultiver les forêts est retardée par la pression politique des activistes de l'environnement et d'autres groupes. En particulier, je pense aux restrictions sur les insecticides et les pesticides enregistrés actuellement. Bien que l'Institut soit en faveur de continuer les recherches sur le contrôle sylviculturel et biologique des insectes, nous reconnaissons que les produits chimiques devront être utilisés pour atteindre les buts de la gestion forestière. Nous expérons, cependant, que nous compterons de moins en moins sur ces produits dans l'avenir. Par conséquent, nous sommes en faveur de l'utilisation responsable des produits chimiques enregistrés dans les forêts. Nous signalons aussi que les ministres canadiens des forêts ont récemment reconnu la nécessité d'utiliser des insecticides et des herbicides dans la gestion forestière. Des rapports publiés par le Newfoundland Medical Society, I'Ontario Medical Association, I'Inverness-Victoria (Nova Scotia) Medical Society et plus récemment par le Juge Nunn de la Nouvelle-Écosse appuient la notion que les produits chimiques enregistrés peuvent être utilisés sans danger.

Une autre cause d'inquiétudes est la tendance de certains gouvernements provinciaux à changer les forêts commerciales en parcs, en régions sauvages, en réserves écologiques, en projets hydro-électriques, en terres à cultiver, en moyens de transports, en moyens de communications et de transmissions, en lignes sismiques, en propriétés résidentielles et industrielles et en endroits de loisirs. Ces décisions ont diminué considérablement le nombre d'arbres coupés chaque année. L'Institut étudiera cette situation en détail pendant la prochaine année.

La formation et la recherche sont deux autres domaines qui 
Advisory Council. Forest research is an investment in the future of our country and has been shabbily treated.

The Institute considers that there is a need to develop a more cohesive structure to bring the forestry community together. The forestry constituency could and should be the largest working constituency in Canada, but it must be organized.

There are a number of voices (1) labour, (2) industry, (3) academic, (4) forestry professionals and the technicians, (5) the CFA federation, (6) private landowners and (7) government, most of which lack cohesion and organization. Some efforts have recently been taken through the establishment of the Canadian Federation of Professional Foresters Associations and planning for a Canadian Forestry Industry Council, while The Association of University Forestry Schools of Canada and meetings of forestry ministers provide forums for university and government dialogue. The Canadian Institute of Forestry and the Canadian Forestry Association will be bringing the various voices together at a meeting to be held tomorrow. Our objective is the eventual creation of a Canadian Forestry Council.

The forestry profession has not done an adequate job in building an awareness on the part of the public, the media, and the politicians that forestry is Canada's number one industry. Indeed forestry represents our most viable megaproject. While I believe that the understanding of the importance of forest resources is improving, each of us has an important role to pursue in this important, but difficult area.

In conclusion, I must express my thanks and appreciation to a number of people. Many have worked hard for the Institute and not all can be mentioned. Special thanks must go to members of our Executive Committee - to 1st Vice-President Gilbert Paillé, to 2nd Vice-President Jim Clark and to Past President George Garner. We have worked together as a team and I am appreciative of their support. Executive Director Bob Bourchier was mentioned previously, and I owe him a debt of gratitude for his fine and capable work since January 1,1983. Doug Redmond has been a tower of strength and I am thankful for his assistance in serving as Secretary-Manager until December 31, 1982. Thanks also to Larry Letourneau, our capable Finance Committee Chairman for the past three years, to Graham Boothroyd who has done a wonderful job as BC Regional Coordinator, to Bruce Denyer our Forestry Chronicle Editor, to Phil Gilbert as Resolutions Committee Chairman in both 1982 and 1983, to Lorne Riley, Chairman HAMPCO 1983 and his committee members, to Phil Cottell, retiring Chairman of the Board of Examiners, to Mrs. Denise Trepanier, our Office Manager and to Heather MacDonald my secretary for all of her help. Thanks also to members of the Board of Directors, Section Officers, Committee Members and individual members for their assistance.

It has been an honour and a privilege to serve as your President. I have had the opportunity to meet many members and to travel widely in our fine country. It has been busy, but it was enjoyable. I am grateful that we have a strong Executive Committee and when this meeting is over and Gilbert Paillé becomes your President, the Institute will indeed be in good hands.

\section{J.H. Cayford}

causent des inquiétudes. Les fonds affectés aux facultés des sciences forestières diminuent et le nombre de professeurs n'est pas suffisant. Nous prévoyons que le nombre de forestiers et de techniciens devra augmenter durant les prochaines 10 à 25 années. Les institutions de formation devront répondre à ce besoin. La recherche forestière au Canada a été négligée depuis longtemps et a atteint un état lamentable. L'agence principale et nationale responsable des recherches forestières, le Service canadien des forêts, a souffert des coupures durant les 15 dernières années. Le nombre de personnes par année disponibles à faire des recherches a diminué de 50 pour cent. Quelques provinces ont récemment annoncé l'élimination ou la restriction de leurs programmes de recherches forestières. Ces diminutions arrivent à une époque où il y eu une augmentation dans le nombre de demandes de renseignements et des besoins technologiques par rapport à la gestion forestière. Les recherches actuelles ne sont pas coordonnées de façon adéquate. Nous appuyons les tentatives du Service canadien des forêts d'établir un conseil consultatif responsable de la recherche forestière au Canada (Canadian Forest Research Advisory Council). La recherche forestière représente un investissement dans l'avenir de notre pays et a été négligée.

L'Institut croit qu'il existe un besoin de développer une structure plus cohésive afin de rassembler la communauté forestière. Le secteur forestier pourrait et devrait, à l'aide d'organisation, devenir le plus grand secteur au Canada.

II existe plusieurs groupes: (1) la main-d'oeuvre; (2) l'industrie: (3) la formation; (4) les professionnels et les techniciens dans le domaine forestier; (5) la fédération de l'Association forestière canadienne: (6) les propriétaires de terres; et, (7) le gouvernement. Ces groupes ne sont pas organisés. À l'aide de l'établissement de la fédération canadienne des associations de forestiers (Canadian Federation of Professional Foresters Associations), de projets pour former un conseil de l'industrie forestière du Canada, de l'Association of University Forestry Schools of Canada et de réunions avec les ministres responsables des forêts, il y a eu des discussions entre les universités et les gouvernements. L'Institut forestier du Canada et l'Association forestière canadienne réuniront tous les groupes demain. Nous avons pour but de créer dans l'avenir un conseil forestier du Canada.

La profession forestière n'a pas fait tout ce qu'elle pouvait pour améliorer les connaissances du publique, des médias et des politiciens au sujet de l'industrie la plus importante au Canada: l'industrie forestière. Cette industrie est le mégaprojet le plus viable. II est essentiel, malgré les difficultés, d'améliorer les connaissances au sujet de l'industrie forestière.

Pour conclure, j'aimerais remercier plusieurs personnes qui ont bien travaillé pour l'Institut. Malheureusement, on ne peut nommer tout le monde. Mille mercis aux membres du Comité exécutif: le 1er vice-président, M. Gilbert Paillé, le 2e viceprésident, M. Jim Clark et le président sortant, M. George Garner. Nous avons travaillé en équipe et je suis reconnaissant de leur appui. Le directeur administratif, M. Bob Bourchier, a déjà été mentionné. Je suis très reconnaissant de son excellent travail depuis le 1er janvier 1983. M. Doug Redmond s'est montré un soutien précieux et je suis reconnaissant de son aide en tant que secrétaire-gérant jusqu'au 31 décembre 1982. Mille mercis à M. Larry Letourneau, le président du comité des finances durant les trois dernières années, à M. Graham Boothroyd, le coordinateur régional de la Colombie-Britannique, à M. Bruce Denyer, l'éditeur du "Forestry Chronicle", à M. Phil Gilbert, le président en 1982 et 1983 du comité des résolutions, à M. Lorne Riley, le président de HAMPCO 1983, et à son comité, à M. Phil Cottell, le président sortant de la commission d'examen, à Mme Denise Trépanier, la gérante du bureau, et à Mme Heather 
MacDonald, ma secrétaire. Merci aussi aux membres du Conseil d'administration, aux agents de Sections, aux membres de comités et aux membres individuels de tout leur aide.

C'était un honneur pour moi d'être nommé président de I'Institut. J'ai eu l'occasion de rencontrer beaucoup de membres et de voyager à travers notre merveilleux pays. J'ai été bien occupé mais le tout a été très agréable. Puisque notre Comité exécutif est efficace, je suis convaincu que l'Institut sera en bonnes mains lorsque M. Gilbert Paillé assumera la présidence.

J.H. Cayford

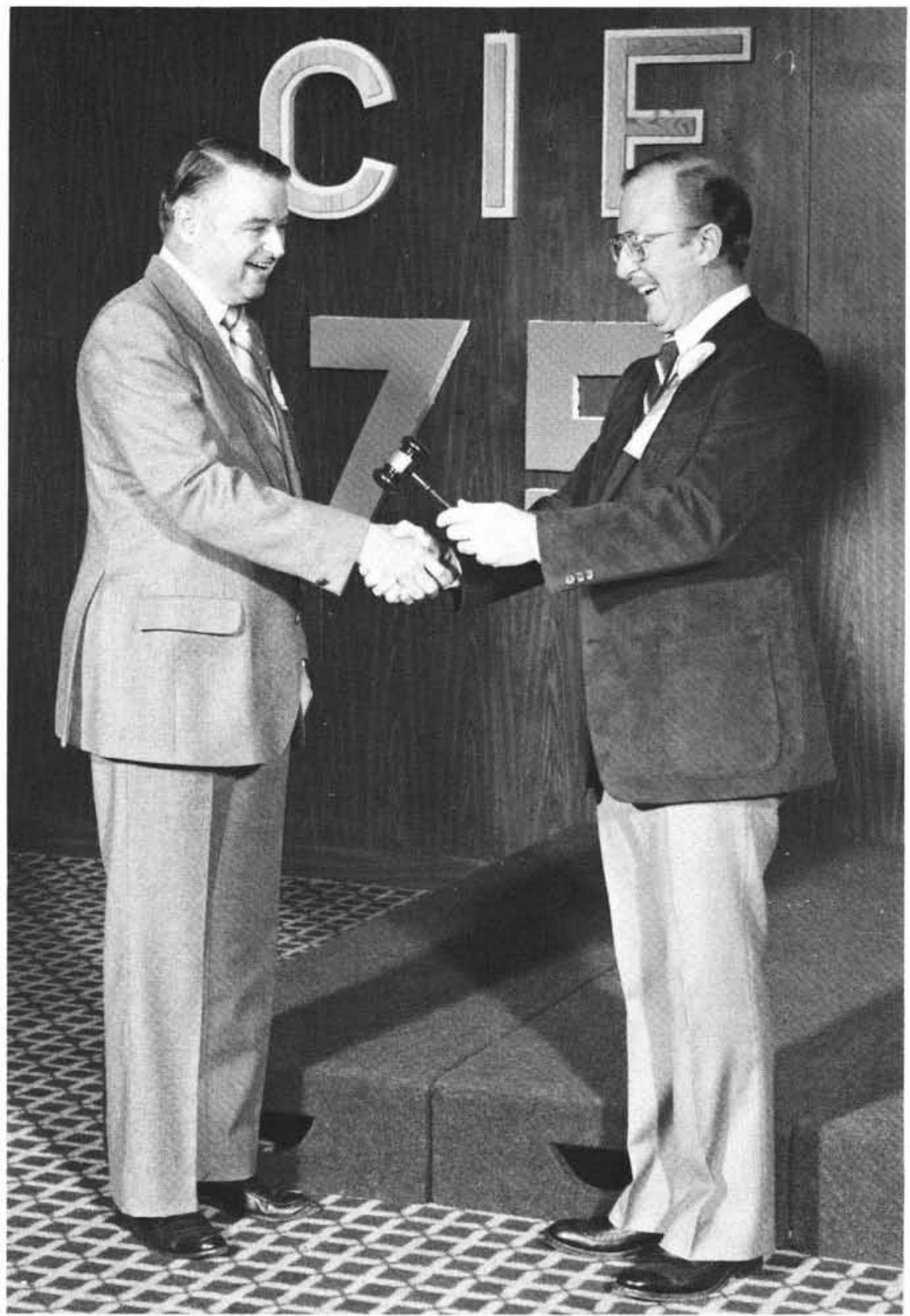

New President Gilbert Paillé receives the gavel from outgoing President James Cayford 


\section{CIF/IFC Executive 1983-84}

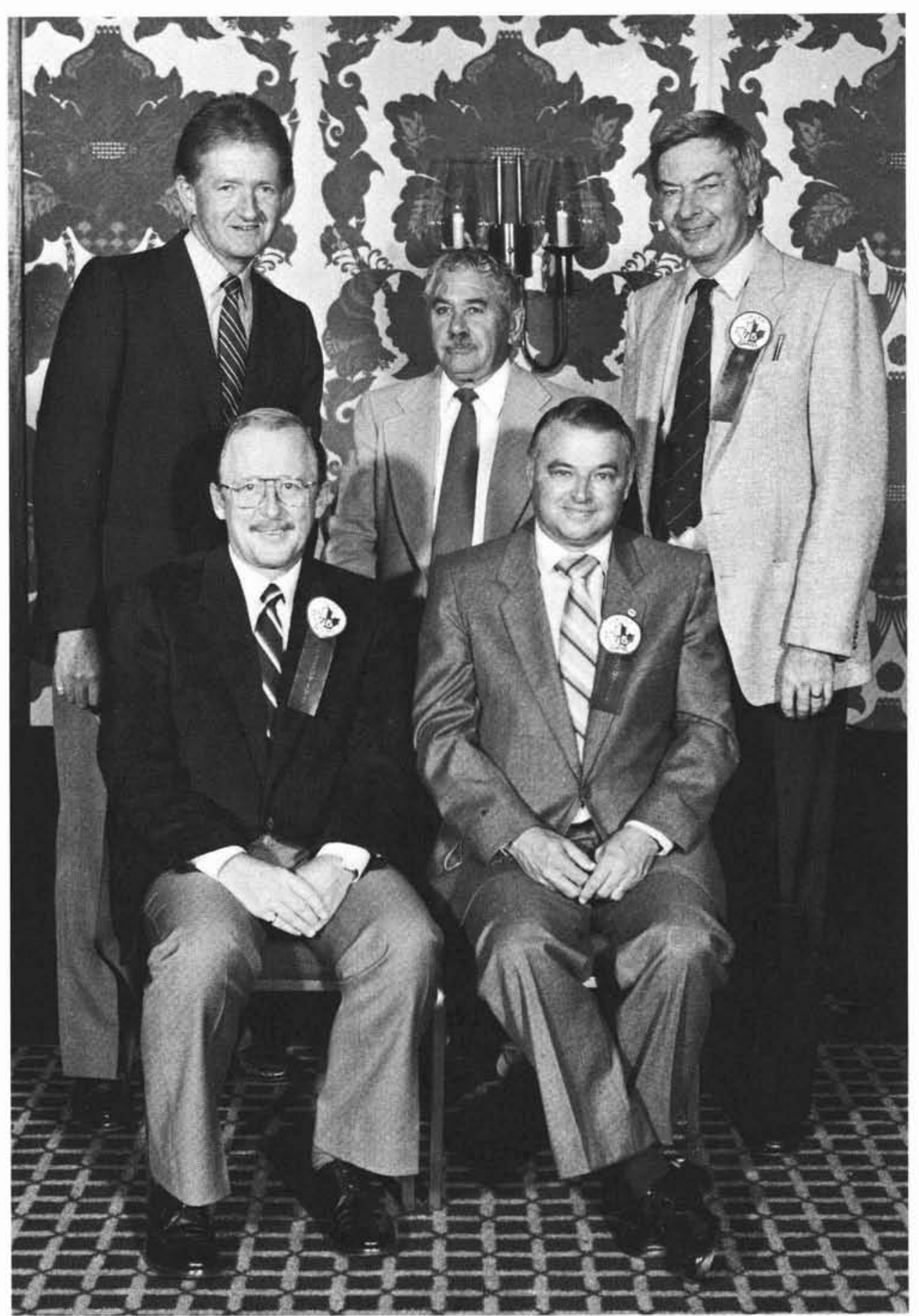

front row L to R: G. Paillée, J.H. Cayford; second row L to R: J.W. Toovey, J.D. Clark, R.J. Bourchier. 


\section{The Executive Director's Report}

Since taking up duties as Executive Director I have been astonished at the rapid passage of time. I am told that it is a sign of job enjoyment although one commentator attributed it to advancing years. It is clearly both with most of the emphasis on job enjoyment!

The work falls into three main categories. I am an administrator, a staff officer and a liaison officer and I will report under these three headings.

\section{Administration}

Membership records continue to take up too much time and effort and they still are not accurate enough but progress has been made as we work out the bugs with the computer service bureau that handles this work. It is clear that a leased microcomputer at about $\$ 300 /$ month will improve performance and cut costs significantly. Research on what equipment to obtain is well along and hopefully we can get underway in the fall. It will of course be necessary to run in tandem for 6 months.

Continuing on the records keeping front, the National Office filing system has been completely reorganized and physically cleaned up with new folders and labels. It speeds work through quicker access and fewer misplaced items. This was made possible through a grant and the diligent work of summer student Darlene Nielsen. There are still some old files that require attention.

Through close cooperation with our auditor and accounting advisor, the accounting system has been streamlined and the accounts coding system much simplified. Institute finances will of course be reported on elsewhere but it is gratifying to note that cost cutting measures in $82-83$ resulted in an essentially break-even result for the year.

The election went smoothly and not one member included his dues payment with his ballot. Doug Redmond's lecture at the Prince George Meeting had a salutory effect. The only complaint received concerning placing the instructions right on the ballot. One member sealed the ballot in the envelope before he had fully read the directions! Our thanks to the Scrutineers Ewen Caldwell and Dr. D.R. Redmond and to volunteer ballot counter Troels Jaeger.

Imperial Life significantly changed the life insurance scheme for members during the year giving markedly increased benefits for the younger age classes. It has been a slow process and resulted in late billing to members and concern expressed by many. At the time of writing new brochures are not yet available from Imperial Life but this should be corrected before the Annual Meeting. Liability insurance for directors and bonding of employees has been arranged.

HAMPCO matters have absorbed some of my time particularly the preparation for the 4 way joint meeting in Quebec in 1984. The HAMPCO manual has been kept current and two further changes are being studied: clearer guidelines for complimentary registration and for partial registration. The rules are very restrictive on these two items at present.

The various certificates presented by the Institute have been reviewed and a more standard format and colour scheme adopted. The Institute now has an adequate stock of certificates in both official languages. A new simplified application form is now in use as well as a membership card that no longer requires individual typing in National Office. (It will be smaller next year). Our supply of sale items has also been expanded modestly. The caps are again in supply in cooler mesh version and a small stock of coffee mugs and coasters has been ordered. This will be further expanded to include low price lapel pins, and probably a bumper sticker.

Concerning our physical facilities most of the seating in the office has been replaced with "user friendly" chairs. The Insti- tute as a whole owes a big vote of thanks to the Ottawa Valley Section for providing a grant of $\$ 1500.00$ to "spruce-up" the office. The funds are earmarked for a small conference table and chairs plus a work counter to hold the postage meter and scales and store related supplies that now rest on or under two very old and scarred tables.

\section{Staff Officer}

The Executive Committee met 5 times in 1982-83:

- Sept. 30, 1982, in Prince George - Executive Committee post conference meeting.

- Nov. 24-25, 1982, in Saskatoon - The director of the Saskatchewan Section, John D. Thompson attended.

- February 8-9, 1983, in Ottawa - The directors or their representatives of the Ottawa Valley Section, (Troels Jaeger), the Algonquin Section (W.R. Clark) and the Champlain Section (Yves Dubé) attended as did the editor of The Chronicle W.B.G. Denyer.

- June 28-29, 1983, in Quebec - The directors of Orleans Section (Jacques Tremblay) and the Champlain Section (François Sauvageau) attended.

- Sept. 29-30,1983, in Sault Ste Marie immediately before the Annual Meeting of the Board of Directors. Preparing for these meetings, recording the decisions and following up the many tasks assigned is one of my major functions.

The Executive for $82-83$ has put in an active year. All but 4 Sections were visited at least once and all the ring ceremonies saw a member of the Executive present.

The Executive met with the Hon. Donald Macdonald, Chairman the Royal Commission on the Economic Union and Development Prospects for Canada, at his invitation, to prepare for the Institute's making a submission. A luncheon was held with the Hon. John Roberts as host, to discuss federal programs. These were also discussed with the Deputy Minister of Environment Canada, Mr. Jacques Gerin at a CIF hosted breakfast. I was charged with responsibility for preparing draft statements and an information package for these important meetings.

Other staff work during the year included coordination of the selection of National Science and Technology Board members, and members of Task Force to prepare the CIF submission to the Macdonald Royal Commission. I act as Executive secretary to these bodies. In addition I am heavily involved in preparing an overview to the statement on herbicide use prepared by the 4 provincial professional associations and the CIF.

\section{Liaison Officer}

It is important to keep CIF policies and viewpoints front and centre before other forestry agencies, governments and industry. To this end I met with a broad spectrum of people from various agencies and continued my role on the University of Toronto Faculty of Forestry Advisory Board. Those contacted or who have contacted me include: International Union of Societies of Foresters, The Committee of Parliamentarians Scientists and Engineers, the Council of Forest Industries of BC, the Agricultural Institute of Canada, Research staff of the NDP party of Ontario, the Canadian Tree Improvement Association, The Assistant Deputy Minister of the Canadian Forestry Service and other CFS senior officers, the Canadian Pulp and Paper Association. The Canadian Forestry Association. The Canadian Wood Council, The Canadian Lumbermans Association, The University of Toronto Faculty of Forestry (Advisory Board and Research Review), The Forest Industry Equipment Exhibition (Advisory Board), The Society of American Foresters (visit to Washington HQ), 
The Federal NDP forestry critic Mr. Lyle Kristiansen and the Canadian International Development Agency. I also participated in the Acid Rain Conference in Quebec in June ' 83 and the Environment Canada Public Consultation in Ottawa in May where I acted as rapporteur for the forestry workshops.

In conclusion I wish to express my sincere thanks to the Executive and to Doug Redmond for their patience and advice during my "break-in" period. Thanks are due also to Denise Trepanier our Office Manager who is a real producer and contributes immeasurably to the operation of the National Office. There has been a very large number of supportive and congratulatory messages sent my way by CIF members across the land. They have meant a great deal to me and I convey my sincere thanks to the senders.

\section{R.J. Bourchier}

\section{Editor's Report}

Many good articles have appeared in the Chronicle in the past year. I must, however, single out two articles for their excellent readability: the Forum article "My fir lady, the New Brunswick production with its facts and fancies", by F.E. Webb and H.J. Irving, and the technical review, "Current status of Bacillus thuringiensis for spruce budworm control", by M.A. Hulme, T.J. Ennis and A. Lavallée. Good technical articles are not created in the first attempt. The latter article underwent a major and a minor revision to appear in its final form.

In the calendar year 1982 (easier to compile than the CIF/ IFC official year), 45 technical articles were submitted for publication in the Forestry Chronicle. Of these 28 have been published, 3 are still under review (received late in 1982), 6 are with the author for revision, and 8 were considered not acceptable for publication. Reasons that the articles were not accepted include: not sufficiently researched, too theoretical, not appropriate or pertinent for the Chronicle.

The system of review for technical articles is: The editor is the person ultimately responsible for the decision to publish or not. He is, therefore, the sole point of contact with the author. The degree of review depends on the complexity of the submitted paper. Review may range from review by the editor only, to a full review by the editor, the appropriate associate editor and two anonymous reviewers, with all degrees in between. Revised papers are reviewed again by the editor only. If the editor thinks the author has made a reasonable attempt to meet the criticism of the reviewers the paper is accepted. I try to keep in mind that it is the author's paper not the reviewers.

It may interest CIF/IFC members to know the schedule for publishing the Chronicle. The cut off date for submission of material for the Chronicle, other than technical articles, is the 15 th of the month prior to the month of publication. This is strictly enforced because every day of delay means the actual publication is delayed by an equal amount of time. Table 1 shows the dates of the various events in publishing the Chronicle for the first half of 1983. Typescripts of material for the Chronicle are sent to the printer who returns galleys. The galleys are pasted up to form the paste-up - a crude representation of how that particular issue will appear. The paste-up along with the corrections to the galley are submitted to the printer who produces a "proof" of the issue. The proof is proof read, corrected, returned. The printer sends the blues - a blue print of the issue in its final form. The "blues" are proof read and returned. The interval between return of the "blues" and actual printing depends on the printer's schedule. The last line of Table 1, is the interval
Table 1. Publishing schedule for the Forestry Chronicle, 1983. Issue

Feb. April June August

Paste-up to printer

Page proofs received

Page proofs returned to printer

"Blues" received

"Blues" returned to printer

Chronicle mailed

Chronicle received in mail by editor
Jan. 23 Mar. 21 May 24 July 25 Feb. 4 Mar. 25 June 2 July 28 Feb. 7 Mar. 28 June 6 July 28 Feb. 16 Apr. 4 June 10 Aug. 4 Feb. 17 Apr. 5 June 13 Aug. 11 Feb. 28 Apr. 19 June 21 Aug. 18 Mar. 9 Apr. 27 June 28 Aug. 23

\begin{tabular}{lcc}
\hline Table 2. Comparative data on the Chronicle pages. \\
\hline \\
Total pages & $1981-82$ & $1982-83$ \\
Pages of technical articles & 323 & 319 \\
Other material & 156 & 142 \\
No. of technical articles & 167 & 177 \\
\hline
\end{tabular}

between mailing the Chronicle in Ottawa and its receipt at the editor's home in Nepean, a suburb of Ottawa. Many members still do not receive their issue of the Chronicle in the month of publication. I hope for some improvement in shortening the time for publishing the Chronicle, but it can't be very much. Advancing the cut off date for accepting material would not really help. Material appearing in the non technical part of the Chronicle would just be a little older.

With M.O.M. Printing, the Chronicle has a first rate, and very cooperative printer. It has been a pleasure to work with the people there.

I think the Chronicle has improved in the last three years, but there is room for a great deal more. The Forestry Chronicle will remain a less than first class publication until it carves out a unique niche for itself, by deciding just what it wants to achieve.

I am relinquishing the job of editor at the end of the year. My three years as editor have been an interesting experience, helped greatly by those associate editors and reviewers who willingly gave so much of their time. I must single out Victor Smith of the University of Toronto, who got much more material to review than any other associate editor. Roy Sutton has done a tremendous job as book review editor. I would also like to thank Marius Pineau, Laval University, for translating many abstracts into French.

\section{W. Bruce G. Denyer, Editor}




\section{Auditors' Report}

We have examined the balance sheet of the Canadian Institute of Forestry - Institut Forestier du Canada as at June 30,1983 , and the statement of operations and deficit for the year then ended. Our examination was made in accordance with generally accepted auditing standards, and accordingly included such tests and other procedures as we considered necessary in the circumstances.

In our opinion, these financial statements present fairly the financial position of the Institute as at June 30,1983 , and the results of its operations for the year then ended in accordance with generally accepted accounting principles.

Cook, Perry, Sewell \& Co.

Ottawa, August 15, 1983

Chartered Accountants

\begin{tabular}{|c|c|}
\hline \multicolumn{2}{|c|}{$\begin{array}{l}\text { Statement of Operations and Deficit for the Year ended } \\
\text { June } 30,1983\end{array}$} \\
\hline \multicolumn{2}{|c|}{ Revenues } \\
\hline Annual meeting & $\$ 2417$ \\
\hline Forestry Chronicle (per schedule) & 43308 \\
\hline Group insurance commission & 2002 \\
\hline Interest on investments & 6340 \\
\hline Members' dues & 144395 \\
\hline Miscellaneous & 589 \\
\hline \multirow[t]{2}{*}{ Sustaining members dues } & 854 \\
\hline & 199905 \\
\hline \multicolumn{2}{|l|}{ Expenditures } \\
\hline \multicolumn{2}{|l|}{ Administration } \\
\hline Accounting services & 1084 \\
\hline Annual meeting & 5834 \\
\hline Depreciation & 93 \\
\hline General expense & 15623 \\
\hline Hospitality & 123 \\
\hline Legal and audit & 7763 \\
\hline Medals, caps, rings and awards & 13422 \\
\hline Office expenses & 7547 \\
\hline Postage & 5293 \\
\hline Rent and hydro & 6544 \\
\hline Telephone & 2428 \\
\hline \multirow[t]{2}{*}{ Translation } & 401 \\
\hline & 66155 \\
\hline Forestry Chronicle (per schedule) & 51344 \\
\hline \multicolumn{2}{|l|}{ Travel } \\
\hline Directors & 8798 \\
\hline Executive & 8362 \\
\hline \multirow[t]{2}{*}{ Executive-Director } & 6982 \\
\hline & 24142 \\
\hline Total expenditures & $\$ 141641$ \\
\hline
\end{tabular}

Excess of total revenues over non-salary expenditures

\section{Salaries}

Casual help

Office

Excess of total expenditures over total revenues for the year

Deficit - beginning of year

Deficit - end of year
Balance Sheet - June 30, 1983

\section{Assets}

\section{Current Assets}

Cash and term deposits

Accrued interest receivable

$\$ 106860$

Government bonds - at cost

(market value - \$11 443)

\section{Fixed Assets}

Office furniture and equipment

Less: accumulated depreciation

\section{Liabilities and Capital Deficiency}

Current Liabilities (note 2)

Accounts payable and accrued liabilities

Dues and subscriptions received in advance

Deficit

Schedule of Forestry Chronicle Revenues and Expenditures for the Year Ended June 30, 1983

\begin{tabular}{|c|c|}
\hline \multicolumn{2}{|l|}{ Revenues } \\
\hline Advertising & $\$ 6679$ \\
\hline Page charges & 6330 \\
\hline Reprints & 7485 \\
\hline \multirow[t]{2}{*}{ Subscriptions and sales } & 22814 \\
\hline & $\$ 43308$ \\
\hline \multicolumn{2}{|l|}{ Expenditures } \\
\hline Editor's honorarium & 6180 \\
\hline Mailing & 4208 \\
\hline Printing & 31712 \\
\hline Production & 496 \\
\hline Reprints & 3370 \\
\hline \multirow[t]{2}{*}{ Sundry } & 5378 \\
\hline & $\$ 51344$ \\
\hline Net cost of operating the Forestry Chronicle & $\$ 8036$ \\
\hline
\end{tabular}

Notes to the Financial Statements for the Year Ended June 30, 1983

\section{Significant accounting policy}

\section{Fixed assets}

Fixed assets are reported at cost. Depreciation is calculated using the declining balance method at the annual rate of $20 \%$.

\section{Contingent liability}

The Institute may be involved in a legal action initiated by its former Secretary-Manager for alleged wrongful dismissal. The Institute is vigorously contesting the claim. Settlement, if any, that may be made with respect to this claim, is expected to be accounted for as a charge against income for the period in which settlement is made.

\section{Other financial information}

The Institute, incorporated Federally as a corporation without share capital, qualifies as a non-profit organization for an exemption from income tax under Federal and Ontario legislation. 


\section{Report of the Finance Committee}

\section{Highlights of Financial Year 1982-83}

The Finance Committee members during the 1982-83 financial year were Mark Schaefer, for the first six months the Acting Secretary-Manager Doug Redmond, for the last six months the Executive-Director Bob Bourchier and myself.

The Committee met five times during the year. Meetings were convened to report on the financial situation of the Institute at the planned Executive Committee meeting.

The 1982-83 financial situation is shown on Table 1. Total expenditures exceeded total revenues by a small amount but both are considerably lower than budget. The slated membership drive for both active members and sustaining members did not take place thus less revenues. Also affecting revenues were significant drops in insurance renewals and in interest rates during the year. Chronicle revenues were up from subscriptions, reprints and page charges but were much lower from advertising.

Higher expenditures than expected were encountered for legal expenses (not budgeted - no way of knowing) and for medals, rings and awards (mostly rings) because of higher metal cost and unusually large graduating classes. Also, more money was spent than was foreseen in general expenses mainly for computer use to produce mailing lists, labels and the updating and purging of these lists. A lot of these expenses will be non recurring and / or reduced through the purchase of a computer. The budgeted staff requirements were not hired thus less was required for salaries and fringe benefits. Travel expenses were down because the Executive did not travel as much as expected and some of the Directors' travelling expenses to the annual meeting were not claimed. Chronicle expenditures benefited from the change of printer and from lower mailing costs. Full mailing costs were budgeted although the change of postage classification was being processed.

Table 1. Comparison of the 1982-83 budget and audit.

\begin{tabular}{|c|c|c|c|}
\hline Item & $\begin{array}{c}\text { Budget } \\
1982-83\end{array}$ & $\begin{array}{c}\text { Actual } \\
1982-83\end{array}$ & $\begin{array}{c}\text { Better (Worse) } \\
\text { Than Budget }\end{array}$ \\
\hline \multicolumn{4}{|l|}{ Revenue } \\
\hline Membership Dues & $\$ 153000$ & $\$ 144395$ & (\$ 8605) \\
\hline Sustaining Membership & $\$ 4500$ & $\$ \quad 854$ & $\$ 3646$ \\
\hline Group Insurance Commission & $\$ 4000$ & $\$ 2002$ & $(\$ 1998)$ \\
\hline Interests on Investments & $\$ 8000$ & $\$ 6340$ & $(\$ 1660)$ \\
\hline Forestry Chronicle & $\$ 41000$ & $\$ 43308$ & $\$ 2308$ \\
\hline Annual Meeting & $\$ 2000$ & $\$ 2417$ & $\$ \quad 417$ \\
\hline Sundry & $\$ 500$ & $\$ \quad 589$ & 89 \\
\hline Total Revenues & $\$ 213000$ & $\$ 199905$ & $(\$ 13095)$ \\
\hline
\end{tabular}

\section{Expenditures}

Administration

Salaries and Employee Benefits

Casual Labour

Office Supplies and Expenses

Rent and Hydro

Postage

Telephone

Legal and Audit

Depreciation

Annual Meeting

Medals, Rings and Awards

General Expenses

Translation

Accounting Services

$\$ 66200$

$\$ 5000$

$\$ 8500$

$\$ 6500$

$\$ 7500$

$\$ 3000$

$\$ 1500$

$\$ 100$

$\$ 5000$

$\$ 8000$

$\$ 3500$

$\$ 1000$

$\$ 1000$

Total Administration

Travel

Executive and Executive Directors

Directors

Total Travel

Forestry Chronicle

Other

Total Expenditures

$\$ 30000$

$\$ 65000$

$\$ 1200$

$\$ 213000$

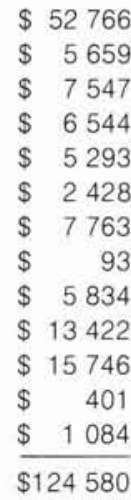

$\$ 13434$

(\$ 659)

\$ 953

(\$ 44)

$\$ 2207$

$\$ 572$

(\$ 6263$)$

$\$ 7$

(\$ 834)

(\$5 422)

(\$12 246)

$\$ 599$

(\$ 84)

(\$7780)

$\$ 2656$

$\$ 3202$

$\$ 5858$

$\$ 51344$

$\$ 13656$

$\$ 200066$

(\$ 161

$\$ 12934$

(\$ 161)

Surplus (Deficit)

Beginning of Year

End of Year
(\$ 12 433)

(\$ 12433$)$
(\$ 12433$)$

(\$ 12 594) 


\section{Budget 1983-84}

The 1983-84 budget is shown in Table 2. Total revenues are expected to rise to $\$ 209,500$, about $5 \%$ over actual revenues of last year. Total expenditures of $\$ 197,800$ would result in an excess of revenues over expenditures for the year of $\$ 11,700$ which would practically erase the accumulated deficit of $\$ 12,594$. This would be in line with the Executive Committee instructions to build up a surplus of $\$ 25,000$ (operating reserve) over the next three years.

\section{Revenues}

Revenues from membership dues and sustaining membership dues will reflect only the higher dues. About the same revenues are expected from insurance commission, interest on investments and the Chronicle that were incurred during the past year

\section{Expenditures}

The changes in policy regarding the ring presentation to new members only and the financing of Directors' travelling by their respective section are contributing to keep total expenditures down. Other expenses are expected to be in line with last year.

\section{Cash Flow}

Cash flow estimates are shown in Table 3. The monthly balance show sufficient money to carry out Institute business if revenues come in as scheduled. Expenditures are more regularly spread throughout the year.

\section{Forecast 1984-85}

Table 2 also shows a forecast of revenues and expenditures for 1984-85 that would yield the first half of the operating surplus asked for by the Executive Committee.

\section{Summary}

The situation at Head Office has now recuperated from the disruptions caused by the move from Montreal and the complete change of personnel. Better control of expenses and revenues is forthcoming and should contribute to better services for the membership in the future.

I wish to thank the members of the Committee - Acting Secretary-Manager Doug Redmond, Executive Director Bob Bourchier and Mark Schaefer - for their work. I also thank the Head Office staff for their help.
On behalf of the Finance Committee, I respectfully submit this report.

Table 2. 1983-84 budget.

$\begin{array}{ll}\text { Budget } & \text { Forecast } \\ 1983-84 & 1984-85\end{array}$

\section{Revenues}

Membership dues

Sustaining membership dues

Insurance commission

Interest on investments

Annual meeting

Miscellaneous

Chronicle

\section{Total Revenues}

$$
\begin{array}{r}
\$ 152000 \\
1500 \\
3000 \\
5000 \\
2000 \\
1000 \\
45000 \\
\hline \$ 209500
\end{array}
$$

\begin{tabular}{|c|c|c|}
\hline Salaries and benefits & $\$ 63000$ & $\$ 66000$ \\
\hline Casual labour & 6000 & 6600 \\
\hline Office supplies & 10000 & 11000 \\
\hline Rent and hydro & 7400 & 7400 \\
\hline Postage & 5800 & 6000 \\
\hline Telephone & 2500 & 2500 \\
\hline Depreciation & 100 & 100 \\
\hline Legal & 1000 & 1000 \\
\hline Subscriptions and hospitality & 600 & 600 \\
\hline Accounting and audit & 1000 & 1100 \\
\hline Translation & 1200 & 1200 \\
\hline Computer services & 4200 & 4500 \\
\hline Annual meeting & 5000 & 6000 \\
\hline Rings, medals, awards & 4000 & 4200 \\
\hline Certificates and novelties & 2000 & 2100 \\
\hline Travel: Executive & 9000 & 9000 \\
\hline Travel: Executive Director & 10000 & 10000 \\
\hline Miscellaneous expenses & 5000 & 5250 \\
\hline Sub-total & $\$ 137800$ & $\$ 144550$ \\
\hline Chronicle & $\$ 60000$ & $\$ 63000$ \\
\hline I Expenditures & $\$ 197800$ & $\$ 207550$ \\
\hline (Loss) & $\$ 11700$ & $\$ 12450$ \\
\hline
\end{tabular}

\begin{tabular}{|c|c|c|c|c|c|c|c|c|c|c|c|c|}
\hline & July & August & September & October & November & December & January & February & March & April & May & June \\
\hline \multicolumn{13}{|l|}{ Revenues } \\
\hline Dues & 12500 & 13000 & 20000 & 6000 & 4000 & 3000 & 3000 & 3000 & 15000 & 30000 & 35000 & 25000 \\
\hline Other' & 300 & 200 & - & 500 & - & - & - & - & - & 1000 & 1000 & 5000 \\
\hline Total & 13100 & 16700 & 22000 & 7500 & 12000 & 12500 & 13000 & 6500 & 17000 & 33000 & 37000 & 32200 \\
\hline \multicolumn{13}{|l|}{ Costs } \\
\hline Chronicle & 8000 & 1500 & 8000 & 1000 & 8000 & 1000 & 13000 & 1500 & 8000 & 1000 & 8000 & 1000 \\
\hline Total & 18000 & 11500 & 18000 & 18750 & 18000 & 12250 & 23000 & 13750 & 18000 & 15000 & 20250 & 12100 \\
\hline BALANCE Opening & 88000 & 83100 & 88300 & 92300 & 81050 & 75050 & 75300 & 65300 & 58050 & 57050 & 75050 & 91800 \\
\hline Closing & 83100 & 88300 & 92300 & 81050 & 75050 & 75300 & 65300 & 58050 & 57050 & 75050 & 91800 & 111900 \\
\hline
\end{tabular}

$$
\begin{array}{r}
\$ 160000 \\
2000 \\
3000 \\
5000 \\
2000 \\
1000 \\
47000 \\
\hline
\end{array}
$$

\section{Expenditures}

Table 3. Cash flow projection July 1983 - June 1984.

Sale of emblems, interest, sundry

2Salaries, office supplies, postage, telephone and telegraph, employee benefits, rent, general

${ }^{3}$ Executive travel, legal, depreciation, audit, annual meeting, medals, awards and rings.

Laurent Létourneau Chairman 


\section{Supplementary Statement to Finance Committee Report, prepared by 2nd Vice-President J.D. Clark.}

Ladies \& Gentlemen:

In my absence, I have asked our executive director, Mr. Bourchier to present to you my comments as follows:

1. Auditor's Report dated August 15,1983, for the fiscal year of the CIF-IFC ending June 30, 1983.

I have reviewed this document and find it to be an accurate indication of the financial situation of the Institute.

I recommend that it be accepted by the membership.

Two (2) audits were done in the past fiscal year; one (1) dated December 31, 1982, to indicate the Institute's financial situation at that date, which coincided with the assumption of duties, of our current executive director, for the Institute. The second audit is the one you have today dated August 15, 1983 .

The audit report indicates the Institute has $\$ 87900$ working capital at June 30,1983 . Our deficit was $\$ 161$ for the 1982-83 fiscal year, and accumulated deficit was $\$ 12594$.

2. The Financial Committee Report for the $1982-83$ year, prepared by the chairman Mr. Laurent Letourneau in cooperation with his members Messrs. Mark Schaefer and Bob Bourchier, reflects the excellent work of this committee. I personally thank this committee for their dedicated work for the Institute.

I recommend the acceptance of this report, with the exclusion of the 1983-84 budget proposal, by the membership.

3. The 1983-84 budget proposal which you will have received is a variation from that proposed by the Finance Committee. The changes to the Finance Committee's proposal were made by your Board of Directors at their October 2 , 1983 meeting and the resulting budget was ratified

The changes made were:

In Revenues

Income from the Chronicle was increased $\$ 2000$ to $\$ 47000$ total.

In Expenditures

- Rings, medals, awards cost was increased by $\$ 11700$ to total $\$ 15700$ since it was a consensus opinion that $\mathrm{CIF} / \mathrm{FC}$ should continue to fund the graduate ring gift in 1983-84

- Directors' travel as a cost of $\$ 9000$ was incorporated into the budget; the Board of Directors at their October 2,1983 meeting directed this item to be maintained as a national office cost.

- The Forestry Chronicle operating cost was reduced by $\$ 3000$ to $\$ 57000$.

The estimated resulting deficit in the 1983-84 budget year is $\$ 4000$; the accumulated deficit is $\$ 16594$

I recommend this budget proposal for your approval.

4. The 1984-85 forecast of revenues and expenditures as submitted by the Finance Committee and ratified by your Board of Directors is recommended for your approval, with the addition of an amount of $\$ 9000$ for directors' travel.

With this cost addition, total expenditures' forecast is $\$ 216550$ and surplus of revenue would be $\$ 3450$. Accumulated deficit would decrease to $\$ 13144$.

5. Discussion

If our current membership can be maintained at approximately 2500 members, and proposed membership dues rates increases are approved, I believe we can improve our Institute's financial results by some $\$ 15000-\$ 20000$ in $1983 / 84$ and in $1984 / 85$. This is a personal assessment. It is an important item to which I will attune my attention.

\section{Proposal: Budget for 1983-84}

Revenues

Membership dues

Sustaining membership dues

Insurance commission

Interest on investments

Annual Meeting

Miscellaneous

Chronicle

Total Revenues

$\begin{array}{r}\$ 152000 \\ 1500 \\ 3000 \\ 5000 \\ 2000 \\ 1000 \\ 47000 \\ \hline \$ 211500\end{array}$

$\$ 63000$

6000

10000

7400

5800

2500

100

1000

600

1000

1200

4200

5000

15700

2000

9000

10000

9000

5000

Miscellaneous expenses

Sub-total

Chronicle

$\$ 158500$

57000

$\$ 215500$

(\$4 000)

Gain (Loss)

Respectfully submitted J.D. Clark, 2nd V.P October 4, 1983 


\section{Forestry Awareness in Canada Trust (FACT)}

1982-83 Annual Report

(July 1, 1982 - June 30, 1983)

1. Registered Charity No.: is 0573469-59-10

2. Trustees:

M.P. Folkema, President FACT

G. Paillé, EC Representative, CIF

R.J. Bourchier, Exec. Dir. of CIF, and Secr. of FACT

E. Heidersdorf, Chairman of CPAC, CIF

3. Main Goal:

The main goal is to produce a book on "Forest Management in Canada". This book will be written in a popular style to stimulate greater public awareness of the importance of Canada's forests and to discuss the current inadequate levels of forest renewal and forest management

The secondary goal of FACT is to promote public awareness through the Sections in any way possible, practical and feasible. To date, no significant progress has been made on this secondary goal because all finances have been required to realize the primary goal.

4. Progress to Date:

D. MacKay started work in September 1982 , on a full-time basis, for a $1 \frac{1}{2}$ year period, to produce a manuscript for FACT. This work is proceeding according to schedule.

Since September 1982, D. MacKay has visited various parts of western, central and eastern Canada to obtain research data, to carry out interviews and to obtain a first-hand knowledge of the forest management/forest renewal situation. Additional visits are planned. budgets permitting. A detailed draft outline of the book has been prepared and reviewed. The book is currently being written.

5. Funds Needed:

To produce a book on "Forest Management in Canada" the funds required are:

$\$ 45000$ for manuscript

$\$ 15000$ for publishing and distribution of "free" copies to media, etc.

During 1982, the CIF Exec. Com. and FACT Trustees supported the objective of also producing a French version of the book. This will add $\$ 15000$ to the total cost. The total combined cost is projected to be $\$ 75000$ for both the English and French versions

6. Fundraising:

A fund raising campaign has been carried out during the past several years. All companies, organizations and government departments involved with the forestry sector have been approached, on a one-time basis, by letter, to provide financial assistance for this project. In addition, many CIF members have provided donations.

To date $\$ 57014$ has been received (see attached statement by R.J. Bourchier). This includes interest income. In addition, $\$ 1500$ in pledges is still outstanding. Also, we hope that the Québec government will make a favourable decision regarding support for the French version. Based on total expenditures of $\$ 75000$, FACT currently faces a deficit of about $\$ 16500$.

This projected deficit was brought to the attention of the CIF Exec. Com, in Feb. 1983. The Exec. Com. and the FACT Trustees hope that by alerting the $\mathrm{CIF}$ membership to this situation that additional funds will be forthcoming. It is hoped that the improving economy in the forestry sector may make it possible for CIF members, companies and organizations to make additional contributions towards this project.

Official receipts for income tax purposes will be sent to all donors. Contributions should be forwarded to:

\section{R.J. Bourchier}

Secretary-Trustee

Forestry Awareness in Canada Trust

Suite 815

151 Slater St.

Ottawa, Ont.

K1P $5 \mathrm{H} 3$

7. List of Donors to Date:

CIF/IFC members

$\$ 7200$

Governments $\$ 22500$

Alberta, Dept. of Energy \& Nat. Resources

British Columbia, Min of Forests

Canada, Dept. of the Environment (CFS)

New Brunswick, Dept. of Nat. Res

Newfoundland \& Labrador, Dept. of For. Res. \& Lands

Nova Scotia, Dept. of Lands \& Forests

Ontario Min of Nat. Res.

P.E.I., Dept. of Agr. \& Forestry

Forest Industries $\$ 22500$

Acadia Forest Products Ltd

American Can of Canada Inc.

Boise Cascade Canada Ltd.

CIP Inc

Consolidated-Bathurst Inc.

Domtar Forest Products

Donahue Inc.
Donahue St. Félicien

Fraser Inc

Great Lakes Forest Products Ltd.

Les Industries James Maclaren Inc.

J.D. Irving Ltd.

Manitoba Forestry Resources Ltd.

Normick Perron Inc.

Northwood Pulp \& Timber Ltd.

Nova Scotia Forest Ind.

Pacific Forest Products Ltd.

Papeterie Reed Ltée.

Prince George Pulp \& Paper Ltd.

Saskatchewan Forest Products Corp.

Scott Maritimes Ltd.

S.E.R. de la Vallée Inc.

Simpson Timber Co.

Spruce Falls Power \& Paper Co. Ltd

St. Regis (Alberta) Ltd

The Pas Lumber Co. Ltd. Weldwood of Canada Ltd.

Weyerhauser

Others $\$ 6800$

Canadian Paperworkers Union

CN Rail

Finning Tractor \& Equipment

Hon. Donald S. Macdonald

Les Consultants Plurifor Inc.

L'Ordre des Ingénieurs Forestiers du Québec

Mercantile Bank of Canada

Ness Companies

New Brunswick For. Products Ass.

Nova Scotia Tractors \& Equip. Co.

Ont. Prof. For. Assoc

Timberjack Inc.

8. Financial Statement for FACT: July 1,1982 to June 30,1983 by R.J. Bourchier

Michael P. Folkema, RPF President

Forestry Awareness In Canada Trust Balance Sheet - June 30, 1983

Assets

\section{Current Assets}

Cash in bank

Term deposits

Equity

Surplus 
Statement of Operations and Surplus for the Year ended June 30, 1983

\begin{tabular}{|c|c|c|}
\hline \multicolumn{3}{|l|}{ Reven } \\
\hline \multicolumn{3}{|c|}{ Donations - corporations } \\
\hline and individuals & $\$ 6673$ & \\
\hline \multicolumn{3}{|l|}{ Donations - } \\
\hline governments & 9800 & \\
\hline Interest income & 5998 & $\$ 22471$ \\
\hline \multicolumn{3}{|l|}{ Expenditures } \\
\hline Salary & $\$ 24000$ & \\
\hline Travel & 3176 & \\
\hline Miscellaneous & 134 & 27310 \\
\hline \multicolumn{2}{|c|}{ Excess of Expenditures } & 48 \\
\hline \multicolumn{2}{|c|}{ Surplus - beginning of year } & 37626 \\
\hline Surplus - end of & & $\$ 327$ \\
\hline
\end{tabular}

\section{Financial Statements}

June 30, 1983

\section{Auditors' Report}

To the Trustees of the

Forestry Awareness In Canada Trust

We have examined the balance sheet of the Forestry Awareness In Canada Trust as at June 30,1983 and the statement of operations and surplus for the year then ended. Our examination was made in accordance with generally accepted auditing standards and accordingly included such tests and other procedures as we considered necessary in the circumstances.

As is usually the case in organizations receiving donations, the verification of such items was impracticable beyond accounting for amounts recorded in the books of the organization.

In our opinion, except for the effect of adjustments, if any, which might have resulted had we been able to verify donations, these financial statements present fairly the financial position of the trust as at June 30,1983 and the results of its operations for the year then ended, in accordance with generally accepted accounting principles.

Cook, Perry, Sewell \& Co. Chartered Accountants Ottawa, September 19, 1983

\section{Report on Canadian Journal of Forest Research}

Although there is no formal relationship between the Canadian Journal of Forest Research and the Canadian Institute of Forestry, initiation of the Journal was largely the result of efforts by the CIF, and we take the opportunity at these annual meetings whenever possible to give members an update on activities at the Journal.

In 1982, 202 manuscripts were received, $10 \%$ more than in 1981.210 manuscripts were received through the first nine months of 1983 , a $40 \%$ increase over last year. Over the past several years, the rejection rate has been in the range of 23-29\%. 153 papers and 1039 pages were published in 1982; it is likely over 170 papers and around 1100 pages will be published in 1983. About one-third of the papers received are from Canadian authors, and the majority of foreign manuscripts are from US authors. In 1983, the proportion of non-US foreign manuscripts has increased to over $10 \%$

The Journal ranks third among 13 Forestry journals, just behind two wood products journals, on the basis of the average frequency of citation for articles by other papers (1981 Journal Citation Reports). This high ranking is a reflection of the quality of manuscripts received and published and the Journal's international scope. Because of its high international ranking and reputation, the Canadian Journal of Forest Research expects to continue to attract the best manuscripts of the best Canadian authors

During the past year, the first formal review paper was published (Martell, D.L. 1982. A review of operational research studies in forest fire management. Can. J. Forest Res. 12: 119-140.) Ideas for other review papers are welcomed by the Editor Because of the number of pages published in recent years, frequency of publication was changed from quarterly to bimonthly in 1983. Although there is no backlog of unpublished papers (all papers ready at closing date are published in the next issue), this increased frequency should reduce the average time for publication by about a month. The first Special Issue of the journal on taiga ecosystems appears in the October issue of the Journal. Readers with ideas for other special issues (based upon a topic, symposium, etc.) are encouraged to discuss them with the Editor.

Finally, I wish to thank all of the reviewers, Associate Editors, and their bosses and supervisors for their efforts in support of the Journal. Neither referees nor any members of the Editorial Board receive compensation for their service.

\section{Publication Policy Committee Report for 1982/83}

Terms of reference

- To maintain a continuing review of existing $\mathrm{CIF} / \mathrm{IFC}$ publications and publication policies.

- To provide advice and guidance to the Editor of the Forestry Chronicle.

- To carry out special assignments dealing with CIF/IFC publications and publication policies as requested by the Executive Committee.

\section{Membership}

J.H. Smyth, D. Lockhart, P.E. Vezina, J.H.G. Smith (chairman)

\section{Accomplishments}

Shortly after the committee was established in Nov. 1982, contents, editorial policy, and other aspects of publication of the Forestry Chronicle were reviewed. A draft position was reported to the Executive Committee on March 18, 1983. Our Committee agreed that the current statement of purpose of the Chronicle is adequate, that the system of Associate Editors appears to be working well, methods for choice of articles need to be improved, sections such as "forum", "for the sake of argument", "forestry developments", "section news", "university news", "research news", "working group news", "book reviews" are followed with much interest by many members and merit a high priority. There should be a distinction between "Scientific and technical articles" and "Case studies and promising new methods" with increasing emphasis on the latter. We suggested that page charges be sought for all articles, where feasible, but suggested "Case studies and promising new methods" be acceptable to the Editor and Associate Editor within the area represented and not required to pass our formal review process.

We have not progressed beyond this preliminary statement but will welcome individual and Section comment on any aspect of Publication Policy, before or during the Annual Meeting at Sault Ste. Marie. After we have an opportunity to meet as a Committee and with the Editor we will prepare a current statement of Policy and respond to any issues that may be drawn to our attention.

\section{J. Harry G. Smith, Chairman}


Membership Committee Report 1982/83

Chairman - R.J. Bourchier

Members - One from each Section

\begin{tabular}{|c|c|c|c|c|c|}
\hline Membership & $\begin{array}{c}\text { Aug. } 6 \\
1982\end{array}$ & $\begin{array}{c}\text { June } 1 . \\
1983\end{array}$ & Change & $\begin{array}{c}\text { Aug. } 15 \text {, } \\
1983\end{array}$ & Change \\
\hline Active & 2111 & 1970 & -141 & 1980 & +10 \\
\hline Affiliate & 103 & 83 & -20 & 91 & +8 \\
\hline Fellow & 29 & 32 & +3 & 32 & - \\
\hline Honorary & 3 & 4 & + & 4 & - \\
\hline Retired Paying & 104 & 108 & +4 & 116 & +8 \\
\hline Non Paying & 85 & 92 & +7 & 94 & +2 \\
\hline \multirow[t]{2}{*}{ Students } & 291 & 166 & -125 & 180 & +14 \\
\hline & 2726 & 2455 & -271 & 2497 & +42 \\
\hline Industry Sustaining & - & 5 & & 5 & - \\
\hline
\end{tabular}

The 1982 figure is artificially high because delinquent members did not get taken off the rolls because of record keeping problems inherent in the move to Ottawa. When this was corrected we in effect recorded 2 years attrition in one year. There is encouraging growth in
Nominating Committee

Nominating Committee: George Garner, Chairman Vlad Korrelus

The Nominating Committee report the following candidates have been nominated: For Second Vice-President Dr. Derek J. Coleman Mr. Jack W. Toovey

For First Vice-President Mr. James Clark

G.J. Garner Chairman membership between January 1,1983 and August 15,1983 . During this period the Institute has had a net gain of 112 members.

R.J. Bourchier Executive Director

\section{Board of Examiners}

For 1982-1983, two applications were reviewed and recommended for Active membership under By-laws 3.2.1(2) and 3.2.2. One request for Affiliate membership under By-laws 3.3.1(1), 3.3.1(2) and 3.3.2 could not be accommodated until the applicant has had 3 more years of acceptable forestry experience.

The question raised from the Algonquin Section, CIF, for a standard CIF definition of "allied science", "recognized university", or "responsible forestry position" needs to be clarified. It is, however, my opinion that "allied science" would include: agriculture, ecology, some branches of engineering, etc. "Recognized universities" would include all of the major Canadian institutions; lesser known and foreign ones would have to be looked at individually. "Responsible forestry positions" would probably include but not be limited to: academic faculty and senior administration in forestry schools; senior administrators in government forestry programs; and senior administrators in industrial forestry programs.

This now concludes my 3 years as a member of the Board of Examiners (19821983 as Chairman). Dr. Marcel Lortie now becomes Chairman, Professor F.M. Buckingham continues in his second year and one new member is to be added (by the Executive, I presume).

Philip L. Cottell Chairman 


\section{Working Groups 1983}

This is the annual report of the Working Groups' coordinator for 1982-1983. A brief report on the activities of each group will be followed by some information concerning the new structure and by general comments and good wishes.

\section{A. Activities of Each Group}

1 - Forest ecology working group. Chairman: R.C. McMinn (1979).

Nothing to report.

2 - Forest economics and policy working group. Chairman: P.J. Duffy (Sept. 1982).

The group is responsible for a new column in the Forestry Chronicle on forest policy issues and developments. The first two columns appeared in April and June 1983. A newsletter was published in March. The chairman has been requested to participate in the CIF task force on the economic union and development prospects for Canada. He has also been asked to take action on a resolution of the last annual meeting on Tax Amendments. $\mathrm{He}$ is preparing for a session at the annual meeting in Sault Ste. Marie, and for action at the 1984 meeting in Quebec City. An annual report has been submitted.

3 - Forestry education working group. Chairman: A.R.C. Jones (June 1983).

Change in chairmanship occurred recently and a meeting of the group is planned for October in Sault Ste. Marie.

4 - Forest Entomology and Pathology working group. Co-Chairmen: G.W. Green (Feb. 1981).

G. Wallis (1979).

A CIF position paper has been prepared on the use of chemical pesticides in forestry. The silviculture working group was also involved in this activity. It has been submitted to the Federation of RPF's for comments, and approved by the Executive Committee on March 30, 1983. A meeting is planned in Sault Ste. Marie.

5 - Forest fire control and science working group. Chairman: P.M. Woodard (Nov. 1980).

Nothing to report.

6 - Forest harvesting working group. Chairman: L.H. Powell (April 1982).

Nothing to report.

7 - Hydrology working group. Chairman: E.D. Hetherington (Sept. 1979).

A comprehensive newsletter was circulated in June.
8 - Land use planning and environmental assessment working group.

Chairman: D.J. Coleman ( 1978).

A joint meeting of this group with the forest management working group is planned for October on the issue of forest land withdrawals. A newsletter has been circulated in May.

9 - Forest management working group. Chairman: H. Chojnacki (July 1982).

A meeting is planned for October in Sault Ste. Marie with the land use W.G.

10 - Forest measurements working group. Chairman: R.E. Keen (June 1982).

Nothing to report.

11 - Forest landscape, recreation and tourism working group.

Chairman: P.J. Dooling ( 1978).

Nothing to report.

12 - Silviculture and tree improvement working group. Chairman: A.K. Hellum (July 1980).

Work was done with the entomology working group on pesticides. A meeting is planned for October on the topic of forest renewal needs.

13 - Urban forestry working group. Chairman: E. Jorgensen ( 1978).

Nothing to report.

14 - Wildlife and fish habitat working group. Chairman: F.L. Bunnell (Feb. 1981).

Nothing to report.

\section{B. The Reorganization}

Most present and immediate past chairmen of working groups together with section officers and members of the board of directors were involved in the reorganization of working groups. The new structure was approved by the executive committee in February 1983, and published in the April issue of the Forestry Chronicle.

Members of the new National Forest Science \& Technology Board were appointed by the President in June 1983. They are:

$$
\begin{array}{ll}
\text { R.J. Bourchier } & \text { J.R. Carrow } \\
\text { T.G. Honer } & \text { A. Lafond } \\
\text { G. Paillé } & \text { M.F. Squires }
\end{array}
$$

The Board will meet for the first time during the next Annual meeting of the Institute in Sault Ste. Marie.

The reorganization also includes the establishment of Section Forest Science \& Technology Committees. Several Sections have already initiated some action to that end. 
The topic will be discussed at the next board of director's meeting.

Comments received so far on the reorganization are mostly positive. We have asked working group chairmen to appoint vice chairmen for their group in order to facilitate their own replacement commencing at the annual meeting of 1985 . We hope many members will show their interest.

\section{General Comments}

This year, too many working groups have been inactive. Good links to be established between Section $S+T$
Committees and the $S+T$ Board, and between working groups and the Board should improve this performance substantially.

Representations were made to create new groups to cover the fields of forest utilization and international forestry. These suggestions will be studied at the next meeting of the Board.

Strong representation should be organized when joint meetings of working groups belonging to SAF-IUSFOIFQ are held in Quebec City in 1984.

August 1983
G. Paillé

\section{International Forestry/ de la foresterie internationale}

The following correspondence from the Chairman of the newly-formed Working Group on International Forestry was circulated to all Section Chairmen:

To: CIF

\section{Section Chairman}

The International Forestry Working Group (IFWG) of the CIF held its inaugural meeting at Sault Ste. Marie. The objectives and immediate pre-occupations of the Group are described in the attached minutes of the first meeting which I request you to share with your Section membership. An important aspect of the Group's work will be to provide to the CIF membership at large a window on international forestry developments. The vehicle for this will likely be a regular newsletter in the Chronicle.

Contributions to the newsletter are expected to come from the IFWG membership. In this connection, I would like to extend an invitation to your section members to advise me of their interest to contribute to the newsletter and to participate in other IFWG activities.

Thank you for your cooperation.

La correspondance suivante a été envoyé du président du groupe d'études sur la foresterie internationale à tous les présidents des sections:

\section{A: IFC}

\section{Président de section}

La rencontre inaugurale du Groupe d'études sur la foresterie internationale $(G E F I)$ de I'IFC a été tenue à Sault Ste. Marie. Vous en trouverez ci-joint le procès-verbal, oủ sont exposés les objectifs et les préoccupations immédiates du Groupe d'études et que je vous invite à faire circuler dans votre section. Un aspect important du travail du Groupe consistera à ouvrir une fenêtre, pour l'ensemble des membres de l'IFC, sur l'évolution de la situation internationale en matière de foresterie. Nous le ferons probablement par le biais d'une chronique régulière dans les pages du Forestry Chronicle, dont les articles devraient être fournis par les membres du GEFI.

A cet égard, j'aimerais inviter vos membres à me contacter s'ils désirent collaborer à la chronique ou participer à d'autres activités du GEFI.

Merci de votre collaboration

Ralph W. Roberts, RPF, Ingf Le Président/Chairman

\section{International Forestry/de la foresterie internationale}

\section{Upcoming events/des événements prévus}

World Forestry Congress/Congrès Mondial Forestier

- First two weeks of June 1985, Mexico City. To be confirmed./Les deux premières semaines de juin 1985, Mexico City. - Confirmation nécessaire.

IUFRO Planning Workshop for Asia on Research and Technology Transfer/UIORF - Atelier pour l'Asie sur des recherches et des transferts de technologie

- Second part of June or first part of July 1984, Sri Lanka or Nepal/juin ou juillet 1984. Sri Lanka ou Népal.

International Poplar Commission 17th Session/Commission Internationale de peuplier $17^{\text {Ieme }}$ séance

- October 1-4, 1984. Ottawa/octobre 14 1984, Ottawa.

Commonwealth Forestry Conference/ Conférènce Foresterie du Commonwealth

- September 8-22, 1985, Victoria, B.C.I septembre 8-22, 1985, Victoria, B.C.

International Symposium on Strategies and Designs for Afforestation, Reforestation and Tree Planting/Conférence internationale sur la stratégie et planification pour l'afforestation, régénération et plantation

September 19-23, 1983, Wageningen, The Netherlands/septembre 19 . 23/83 Wageningen, Pays-Bas.

\section{News Item/des nouveaux}

IUFRO has established a new Working Party entitled "Evaluation of Forestry Research", S6.06-01. Contact: Dr. Callaham, University of California, Berkeley/Un nouveau groupe de travail formé par UIORF (S6.06-01) intitulé "évaluation de recherche forestière". Contact: Dr Callaham, Université California, Berkeley.

\section{Recent Events/événements récents}

UNIDO/FAO First World Consultation on Wood and Wood Products / ONUDI/OAA première consultation mondiale sur le bois et des produits de bois

- September 1983, Helsinki/septembre 1983, Helsinki

FAO Committee on Forest Development in the Tropics, Sixth Session/Comité d'OAA sur le développement forestier tropical, $6^{\text {leme }}$ séance

- October 1983, Rome/octobre 1983. Rome.

For more information:

G.A. Steneker - Secretary - IFWG

CFS

Ottawa K1A $1 \mathrm{G} 5$

Pour plus de renseignement:

G.A. Steneker - secrétaire - GEFI

SFC

Ottawa K1A $1 \mathrm{G} 5$ 


\section{Silviculture and Forest Tree} Improvement Working Group

\section{Activitiés sylvicoles au Québec 1981-1982}

La récolte de bois sur forêt publique s'est élevée à un peu plus de 24 millions de $\mathrm{m}^{3}$, prélevés sur une superficie approximative de 240000 ha. Quant à la forêt privée, elle a fourni $6718000 \mathrm{~m}^{3}$, soit près de 22 pour 100 du total. Compte tenu de l'importance de cette dernière, les travaux en forêt privée, pour lesquels des données sont disponibles, ont été inclus dans le tableau qui suit. Ce sont essentiellement des travaux subventionnés, pour lesquels un contrôle des activités est possible.

Dans un effort concerté pour obtenir une image de la régénération naturelle en forêt privée, des inventaires de régénération ont été menés sur plus de 100000 ha Quant aux forêts publiques, le programme régulier a été poursuivi.

Pour fournir les semences nécessaires au reboisement, on a récolté 10839 hectolitres de cônes, principalement dans le pin gris et l'épinette noire; la fructification a été très faible pour les autres essences. L'amélioration génétique s'est poursuivie par des travaux sur 237 ha de peuplements semenciers et de vergers à graines, et par la sélection de 3249 arbres-plus. Enfin 8000 greffes furent réalisées au nouveau centre de greffage de Duchesnay

La production de plants a atteint plus de 37 millions d'unités, dont près de 10 pour 100 de plants en récipients. Ils ont servi à reboiser environ 18000 ha, à raison de 65 pour 100 du total sur forêt privée. Quant à l'ensemencement aérien ou terrestre effectué sur forêt publique, il a couvert un peu plus de 10000 ha. Enfin, plus de 8150 ha de régénération artificielle des années antérieures on fait l'objet de travaux d'entretien, de regarnissage ou de dégagement.

Les traitements sylvicoles dans les forêts naturelles ont touché environ 18000 ha, dont près de 60 pour 100 en forêt privée. Les éclaircies commerciales, incluant les coupes de récupération et d'assainissement, représentent les deux tiers de ce total.

\section{Silvicultural Activities in Quebec 1981-82}

Timber harvest on the public forest has reached slightly more than 24 million $\mathrm{m}^{3}$ from some 240000 ha. Private forests have yielded $6718000 \mathrm{~m}^{3}$, almost 22\% (sic). The following table includes those works on private forests for which data are available illustrating their significance. These are essentially funded works which are subject to supervision.

To obtain an overview of natural regeneration on private forests, regeneration surveys have been carried out over more than $100000 \mathrm{ha}$. The regular program has been continued on public forests.
Sommaire des traitements syivicoles effectués au Québec en 1981-1982

\begin{tabular}{lcc}
\hline Activité & Forêt publique & Forêt privée $^{1}$ \\
\hline Récolte de cônes (hectolitres) & 10839 & \\
Peuplements semenciers (ha) & 108 & \\
Vergers à graines (ha) $^{2}$ & 129 & \\
Production de plants ('000) & & \\
$\quad$ à racines nues & 34124 & \\
$\quad$ en récipients & 3285 & 100825 \\
Inventaires de régénération (ha) & 81000 & 1867 \\
Scarifiage (ha) & 16140 & 11550 \\
Plantation (ha) & 6225 & \\
Ensemencement (ha) & 10399 & 1504 \\
Entretien de la régénération (ha) & 6649 & 987 \\
Eclaircies précommerciales (ha) & 5924 & 9423 \\
Eclaircies commerciales et & & \\
récupération (ha) & 1400 & 6718 \\
Récolte de bois ('000 m³) & 24082 & \\
\hline
\end{tabular}

Travaux subventionnés seulement

2Divers travaux, incluant l'établissement de nouveaux secteurs et l'entretien des secterus établis

3Superficie calculée sur la base de 2100 plants/ha.
To provide the seed needed for reforestation, 10839 hectolitres of cones have been collected, mostly white pine and black spruce; flowering was sparse in other species. Genetic improvement is continuing on 237 ha of seed-tree stands and seed orchards and by selection of 3249 plus trees. Also, 8000 grafts were made at the new Duchesnay grafting centre.

More than 37 million seedlings were raised, about $10 \%$ in containers. They were used to reforest 18000 ha, $65 \%$ on private forests. Slightly more than 10000 ha were direct seeded from the air or on the ground. Lastly, more than 8150 ha of earlier plantings received maintenance weeding or release treatments

Silvicultural treatments were carried out on some 18000 ha, about $60 \%$ in private forests. Commercial thinnings including salvage and sanitation cuts make up two thirds of this total.

René Douce Le 21 juillet 1983

\section{Wildlife and Fish Habitat Working Group}

Fourteen members of Working Group N met at the Annual Meeting in Prince George. Discussion addressed the then proposed changes to Working Group structure and the problems with geographically clustered membership. Comments on structure were forwarded to Paille and were similar to the structure that has since evolved. No imaginative solutions to clustered membership were proposed. Members of the Working Group in BC and Ontario have since been actively involved in the planning and organization of the ForestryWildlife Management Symposium to be held at UBC in May 1984. Members are active on the National Steering Committee, BC Host Committee, and several subcommittees 


\title{
Canadian Institute of Forestry/Institut Forestier du Canada
}

\author{
75th Annual General Business Meeting \\ October 3 and October 6, 1983 / Holiday Inn, Sault Ste. Marie, Ontario
}

\author{
Minutes
}

1.

\section{Opening the Meeting}

Immediately prior to the meeting, the opening of the convention was presided over by Lorne F. Riley, Chairman of the Host Annual Meeting Planning Committee (HAMPCO '83). Greetings and welcome were extended by Mayor Don McGregor of Sault Ste. Marie and Mr. J.H. Smyth, Chairman of the Central Ontario Section. The Honourable Russel Ramsay, M.P.P. and Mr. R. Irwin M.P. spoke briefly welcoming the delegates and outlining their views on some of the problems and opportunities inherent in managing the nation's forest resources.

President Jim Cayford opened the 75th Annual General Business Meeting with a short history of his home city, Sault Ste. Marie and noted that the 42 nd meeting of the Institute had been held there in 1950. He announced that P.G. Gilbert was again chairing the Resolutions Committee assisted by J.W. Toovey, Y.J. Hardy and R.A. Haig. He urged delegates to get their resolutions to $\mathrm{Mr}$. Gilbert as soon as possible and emphasized that the deadline would be 9:00 a.m. Wednesday, October 5 .

2.

President Cayford read the names of members deceased during the past year and asked delegates to stand and observe a moment of silence in their memory. They are:

R.M. Dixon Southern Ontario

R.H. Ness Southern Ontario

C.D. Schultz Vancouver

W.G. Sherrick Maritimes

G. Poire Orleans

J.C. Curry Nova Scotia

Vernon Bastin Maritimes

D.O.L. Schon Vancouver Island

3.

Minutes

The minutes of the 74th Annual General Business Meeting were published in the Annual Meeting supplement of the December, 1982 Forestry Chronicle. The President asked for omissions or corrections. There were none. MOTION G83-1 (J.F. Flowers, C. Glerum) That the minutes of the 1982 meeting be approved as printed.

Carried

4.

4.1 President's Report

The President's report was re- ceived with applause. It will be published.

4.2 Executive Director's Report

The Executive Director presented highlights of his report. MOTION G83-2 (P.J.B. Duffy, R.J. Stoddart) THAT the Executive Director's Report be accepted

Carried

\subsection{Editor's Report}

The Editor's report was presented by the Executive Director in the Editor's absence.

MOTION G83-3 (R.J. Bourchier, $R$. Doucette) THAT the editors report be accepted.

Carried

\section{$5 . \quad$ Awards}

5.1 Golden Year Award

The President announced that there was only one award in 1983 to Dr. R.E. Balch of Maritimes Section.

5.2 Fellow Members

The President announced that Alfred Kabzems of the Saskatchewan Section had been elected to Fellow Member status at the Board of Directors Meeting.

\subsection{Foresters Rings}

The President reported that the Institute had presented 412 rings to the graduating classes at the six forestry schools in 1983

5.4 Gold Medals

The President read the names of the 6 medal recipients for 1983 . Articles on each recipient are appearing in the Forestry Chronicle.

5.5 Schlich Award

The President noted that the Schlich Award had been awarded to a UNB student and that a brief article had appeared in the Forestry Chronicle.

5.6 Canadian Forestry Achievement Award

The President announced the 1983 winner, Mr. Duncan Naysmith who then stepped to the platform to hear the President read the citation and to receive the award.

5.7 Canadian Forestry Scientific Achievement Award

The President announced the first 1983 winner. Dr. J. André Fortin who then stepped to the platform to hear Dr. Paillé read the citation and to receive the award.
The President then announced the second 1983 winner, Dr. J.T Basham who stepped to the platform to hear Mr. Cayford read the citation and to receive the award.

\section{Forest Science and Technology} Board and Working Groups

First Vice President Gilbert Paillé reported on the activities of the working groups during 1982-83. He noted that some working groups had been inactive during the year but that the newly created Forest Science and Technology Board should provide a focus for future activities and would be reviewing the science and technology program of the Institute. The report on working groups will be published in the 1983 Chronicle supplement.

The meeting was adjourned at 11:45 a.m. to meet again October 6th at 9:00 a.m.

The meeting continued at 9:10 a.m. October 6th. G.M. Bonnor of Algonquin Section regretfully announced that $\mathrm{Mr}$ E.C. Little of that Section had died in the preceding few days.

\section{Report on Committees}

President Cayford reported briefly on the activities of the various national committees.

\subsection{Natural Areas}

A revised draft CIF policy statement on natural areas has been prepared. It will be published.

7.2 Board of Examiners

The new Chairman is Prof. Marce Lortie. The continuing member is Prof. F.M. Buckingham. Prof. J.K. Rothwell of the University of Alberta is the new member of the Board for 1983-84.

7.3 Memberships

Membership as of August 15 is 2497. This represents a net gain of 112 since January 1983 . It was noted that over 400 members had yet to pay their 83-84 dues.

7.4 Publications Policy A preliminary statement has been prepared and the committee will prepare a definitive statement during 1983-84.

7.5 Resolutions

A statement on procedures for handling resolutions has been prepared and endorsed by the Executive Committee. This statement will be published in the Chronicle. 
7.6 Organization and Structure The President had asked Past President Devitt to study this question and Mr. Devitt reported to the Board of Directors at its meeting at Sault Ste. Marie. He recommended that a task force be set up to prepare a second 5 year plan for the Institute. The Board has created this task force with the following membership: C.M. Johnson VI; R.J. Stoddart, Sask; Peter Gagnon, L.W.; R.J Hatcher, OR; Ken Snow, N.S. Executive Committee rep; Ex Dir.

8.

\section{Finances}

The President introduced the topic and noted that the budget proposed by the Finance Committee for 1983/ 84 had been revised by the Board of Directors to provide for the continuation of the ring ceremony and the payment of Director's travel by the National office of the Institute. The Executive Director then read a statement prepared by Vice-President Clark that further elaborated on the revised $83 / 84$ budget and other financial issues. This statement and the revised budget will appear along with the Finance Committee's report in the December 1983 Supplement to the Forestry Chronicle.

8.1 Auditors Report

MOTION G83-4 (L.A. Letourneau J.H.G. Smith) THAT the auditors report be accepted.

Carried unanimously

\subsection{Finance Committee}

Chairman L.A. Letourneau summarized the report excluding the $83 / 84$ budget, the $84 / 85$ forecast and the $83 / 84$ cash flow projection noting the changes made by the Board of Directors.

MOTION G83-5 (L.A. Letourneau, G.W. Green) THAT the Finance Committee Report be accepted.

Carried

\subsection{The 1983/84 Budget}

The Executive Director outlined the proposed budget as revised by the Board of Directors. MOTION G83-6 (R.J. Bourchier, J.F. Flowers) THAT the 1983/84 budget as revised by the Board of Directors be approved.

Carried

8.4 Budget Forecast for 1984/85

This item was not discussed.

8.5 Appointment of Auditor

MOTION G83-7 (D.A. Hall, W.J.B. Devitt) THAT Cook. Perry and Sewell \& Co. of Ottawa be appointed as auditors for the CIF for the 1983-84 fiscal year provided that satisfactory arrangements can be made and failing such, that the Executive Committee be authorized to make other arrangements.

Carried

President Cayford expressed the thanks of the Institute to Laurent Letourneau for his outstanding service as Finance Committee Chairman. - Lengthy applause.

\section{Rules and Regulations}

9.1 Rule 1 on Committees MOTION G83-8 (J.A. Kayll, W.J.B Devitt) THAT Rule 1 be amended by adding the words "and boards" after each appearance of the word committee(s) except when the Executive Committee is being referred to.

Carried

9.2 Rule 3.1 on Annual Dues MOTION G83-9 (W.J.B. Devitt, Kathy Hopkins) THAT Rule 3.1 be amended in accordance with the recommendations of the Executive Committee and the Board of Directors to provide for dues effective July 1,1984 as follows:

\section{Active Members}

1 st and 2 nd year graduation (grad 1984, grad 1983)

$\$ 59.00$

All other Active Members

$\$ 83.00$

\section{Affiliate Members}

1 st and 2 nd year after after graduation (grad 1984, grad 1983)

All other Affiliate Members

Members with Retired Status receiving For. Chronicle

Members with Retired Status not receiving For. Chronicle $\$ 59.00$ $\$ 78.00$ Student Members

$\$ 25.00$

$\$ 00.00$ $\$ 25.00$

\section{Sustaining Members}

Sustaining Members (CIF)

Sustaining Members (Other)

$\$ 25.00$

$\$ 200.00$

Carried

9.3 Rule 3.5 Chronicle subscriptions MOTION G83-10 (W.G. Camenzind, D.W.J. McGowan) THAT annual subscriptions to the Forestry Chronicle for 1985 will be $\$ 26.50$ in Canada and $\$ 31.50$ in other countries. Subscriptions to multi-users (eg. libraries) will be $\$ 52.50$ in Canada and $\$ 63.00$ in other countries. The price of single copies not more than two years old shall be $\$ 5.00$ postpaid to any destination and for those more than two years old the price shall be $\$ 10.00$ postpaid to any destination. All prices in Canadian funds.

Carried

\subsection{Rule 4.2 Resolutions}

MOTION G83-11 (Kathy Harper. L. Ringham) THAT Rule 4.2 be amended by deleting the words "the preceding June 1" and replacing them with the words "five weeks in advance of the Annual General Meeting"

\section{Carried}

\section{Forestry Awareness in}

\section{Canada Trust. (FACT)}

In the absence of Mr. M. Folkema, President of FACT, 1 st Vice-President Paillé summarized the report which will be published in the December
1983 supplement to the Forestry Chronicle. Collections now total some $\$ 65000$ and a further $\$ 10000$ is required to publish. Mr. Don MacKay's book in both official languages.

11. Editor and Production Manager, Forestry Chronicle

President Cayford noted that Dr. Denyer will resign his editors duties January $1 / 84$ but will continue as production manager. The Board of Directors has approved a contract with $\mathrm{Dr}$. I.C.M. Place of Ottawa to act as editor.

\section{Future Annual Meetings} President Cayford pointed out that the schedule is now a regular feature of the Forestry Chronicle as follows:

1984 in Quebec Aug 6-9; 1985 in Winnipeg Sept. 23-26; 1986 in Victoria Sept. 22-25. He also reported that the Board of Directors had accepted the invitation of the Newfoundland Section to host the 1987 meeting in Saint Johns.

13.

\section{Resolutions}

The Resolutions Committee was ably chaired by P.G. Gilbert of Vancouver Section. Other members were R.A. Haig CO, Yvan J. Hardy OR, and J.W. Toovey VA

\subsection{Ratification}

Resolution 83-1 (P.G. Gilbert, R.A. Haig) BE IT RESOLVED that the members of the CIF/IFC at the 75th Annual Meeting ratify, sanction and confirm all acts, covenants, and proceedings made, taken or entered into on their behalf by the Board of Directors and by the Executive Committee during the past year.

Carried

13.2 Other Resolutions

Resolution 83-2 (W.R. Clark, B.D. Haddon, C.W. Yeatman) WHEREAS attainment of the objective of the CIF/IFC "to improve all aspects of forestry in Canada" will require the cooperative and full involvement of both professionally and technically trained persons, and WHEREAS CIF/IFC has wisely made provision for technically trained people and for people with forestry-related degrees through an affiliate class of membership, and

WHEREAS the current enrolment of affiliate members is very low at only 103 people which is thought to be a reflection of an inappropriately-high fee schedule for affiliate members who have no national CIF/IFC voting rights.

THEREFORE BE IT RESOLVED that the CIF/IFC Executive initiate a detailed review of the fee structure as it relates to affiliate members, including consideration of a major fee reduction for affiliate members to encour- 
age more technically-trained people, and those with forestryrelated degrees, to join and to participate in the CIF/IFC

Carried

Resolution 83-3 ( $Y$. Dube, $F$. Sauvageau)

Etant donné que le "Forestry Chronicle" sous sa forme actuelle n'atteint pas un de ses buts déclarés soit d'encourager une meilleure compréhension de la foresterie.

II est donc recommendé que $\mathrm{CIF} / \mathrm{IFC}$ encourage la produc. tion d'articles scientifiques et vulgarisés dans le "Forestry Chronicle" sur les domaines forestiers de l'heure, à des fins de publication et de distribution élargies pour atteindre d'autres publics cibles.

WHEREAS "The Forestry Chronicle" in its present form does not reach one of its established goals, namely to establish a wide understanding of forestry. THEREFORE, be it resolved that the $\mathrm{CIF} / \mathrm{IFC}$ request more scientific and popular articles in "The Forestry Chronicle" on present forestry aspects for enlarged publication and distribution to reach other target audiences.

Carried

Resolution 83-4 (J.W. Toovey, D.W. Maclean and F. Sauvageau)

WHEREAS the Forestry members of the Canadian Council of Resource and Environment ministers, at their meeting in Winnipeg on September 14, 1983. recognized "that there is currently a need for the use of both insecticides and herbicides in managing the nation's forests", and

WHEREAS these same ministers also "emphasized the need to communicate with the public about the use of chemicals for forest renewal and protection". THEREFORE, be it resolved that the CIF/IFC now commend these ministers on adopting a very positive stance on the use of chemicals in forest management in Canada, and offer the $\mathrm{CIF} / \mathrm{IFC}$ services to assist in the education of the Canadian public on this very important matter.

Carried

Resolution 83.5 (G.M. Bonnor, M.H. Clarke)

WHEREAS the government of Ontario, through the Ontario Tree Improvement and Forest Biomass Institute, heretofore has indicated a positive commitment to forest research programs as an essential and indeed critical component of all silvicultural programs, and

WHEREAS the need for such research is continuing to increase as forest renewal and intensive forest management programs are being acceler ated, and

WHEREAS the Ontario minister of Natural Resources has recently indicated that the Minis try now intends effectively to divest itself of the facilities and staff of the Tree Improvement and Forest Biomass Institute in light of a changed attitude within the Ministry toward research as a legitimate ministry activity. THEREFORE, be it resolved that the Executive of the CIF/IFC now express to the Ontario Minister of Natural Resources the very deep concern of the members of the CIF/IFC abou his Ministry's announced intentions for a reduced direct research involvement, and request an early clarification of the details and rationale involved, as well as urging the maintenance of the past year's financial commitment and direct involvement as the minimum level required to sustain the momentum of the current research programs in Ontario. Carried

Resolution 83-6 (P.W. Ackhurst H.E. Pratley, A. Jeffrey, J.A.F Gardner)

WHEREAS the CIF/IFC has for many years enthusiastically advocated the need for a separate federal ministry of forests. and

WHEREAS the report on "Canada's threatened forests" prepared by the Science Council of Canada in March 1983 featured. as its first recommendation, the need for a new federal ministry of forests, and

WHEREAS, in his July 11,1983 letter to the CIF/IFC, Prime Minister P.E. Trudeau clearly supports the status quo of maintaining forestry as a minor component of the Department of the Environment

THEREFORE, be it resolved that the CIF/IFC executive again recommend to the prime minister of the day that an organizational change is necessary whereby forestry will become a major component of a ministry which primarily has responsibilities for resource and economic activities and programs

Carried

Resolution 83-7 (R.W. Beaumont, B.J. Sauder)

WHEREAS the economic recession of the last two years is not yet over, and

WHEREAS governments need to maintain and enhance the basic forest resource through good times and bad in order to realize the potential short-term and long-term social and economic benefits therefrom.

THEREFORE, be it resolved that the CIF/IFC executive and Sections and members take advantage in 1983/84 of every available opportunity to stress to the federal government, to the provincial government, and to the public, the continuing urgent need to invest in the forest resource even during times of necessary overall economic restraint.

Carried

Resolution 83-8 (J.A.F. Gardner, A.J. Kayll, J.K. Jeglum)

WHEREAS the natural areas committee of the CIF/IFC is a member of the Canadian Council of Ecological areas and is a supporter of the principle of establishing ecological reserves in forest and other ecosystems as gene pools, areas for benchmark research activities, and for other scientific and educational uses, and

WHEREAS it is important that such areas be selected and established in a planned and orderly manner, and that there be appropriate protection and management plans for each such area, and

WHEREAS the current ecological reserves programs throughout Canada are in some cases perceived to be lacking adequate constructive assistance from local foresters.

THEREFORE, be it resolved that the Sections and members of the CIF/IFC actively encourage and support the orderly identification, selection, protection and management programs for fores ted ecological reserves.

Carried

Resolution 83-9 (A.R.C. Jones, H.J. Johnson, R.P. Yanni)

WHEREAS, recognizing the urgent need to ensure long-term wood supplies to sustain Canada's forest industry, the federa government produced in September 1982 a policy paper entitled "A Framework for Fores Renewal", outlining the magnitude of the expenditures required, how these might be shared among senior governments and industry, and proposing that the principal mechanism for achieving forest renewa objectives should be a new generation of federal-provincia forestry agreements, based on guidelines set out in the policy paper, and

WHEREAS in his address to the CIF/IFC annual meeting on October 3, 1983, the Honorable Charles Caccia, Federal Minister of Environment, reconfirmed his commitment to this initiative. and 
WHEREAS the existing federal/ provincial forestry agreements, for British Columbia, Ontario, Quebec and New Brunswick all expire at the end of the current fiscal year, and

WHEREAS it is understood that negotiations are progressing smoothly with respect to agreements for the provinces of Alberta, Saskatchewan and Manitoba,

THEREFORE, be it resolved that the CIF/IFC executive urge the federal government and the appropriate provincial government to negotiate with all possible speed to ensure that new agreements focussing on expanded forest renewal and intensive forest management programs become effective by April 1, 1984.

Carried

Resolution 83-10 (J.H.G. Smith, C.A. Steel, A. Jeffrey, R.W. Udell, L.A. Letourneau, C.M. Johnson) WHEREAS the CIF/IFC is celebrating its 75th Anniversary in Ontario, and

WHEREAS the forests of Ontario have supported and should continue to play a significant part in the economic, social and environmental well-being of the province as well as of Canada, and WHEREAS the development of forestry throughout the years in legislation, education, private land reforestation, and crown forest land practices and uses has provided and should continue to provide benefits, not only to Ontario, but also, by example, to other jurisdictions, THEREFORE, be it resolved that the CIF/IFC congratulates Premier William Davis and the Honourable Alan W. Pope, Minister of Natural Resources, on the outstanding progress that Ontario already has made in many aspects of forestry, and encourages the province to continue its leadership role and to accelerate its progress in forest resources management to the benefit of present and future Canadians.

Carried with 18 abstentions Resolution 83-11 (Y.J. Hardy. J.H.G. Smith, V.J. Nordin) WHEREAS there is an acknowledged lack of young forest researchers to meet tomorrow's research needs in forest management in Canada, and

WHEREAS the Science Council of Canada in a 1983 statement on Canada's forests has pointed out the need for more forest research, and

WHEREAS university researchers need greater financial support for their programs of graduate studies and research.
THEREFORE, be it resolved that $\mathrm{CIF} / \mathrm{IFC}$ endorse and bring to the attention of the proper authorities the Science Council of Canada's recommendation that the Natural Sciences and Engineering Research Council should be encouraged in its forestry development program and should "establish a renewable resources management grants selection committee in order to stimulate research related to advanced practices in forest management"

Carried

Resolution 83-12 (D.E. McMullen, C.M. Johnson, R. Elder) WHEREAS it is necessary for CIF members to inform and educate the public on forestry issues, and

WHEREAS it is necessary that significant forestry issues be fully understood and explained, THEREFORE, be it resolved that the CIF/IFC executive committee encourage more Section councils and members to actively pursue the Institute's objective No. 2 - "to foster public understanding of forestry...". By providing immediate written responses to articles or letters contained in their local newspapers or national magazines which appear to mislead the public on significant forestry issues, and to support in a similar public fashion those issues which promote improved forestry practices.

Carried

Resolution 83-13 (P.G. Gilbert, Y.J. Hardy)

WHEREAS the 1983 annual meeting of the CIF/IFC in Sault Ste. Marie has been so successful in exploring the timely 75 th anniversary theme "Forestry in Canada: Yesterday-TodayTomorrow" while at the same time providing most interesting technical field tours and a great social success,

THEREFORE, be it resolved that the delegates to this meeting applaud and heartily thank the Central Ontario Section and HAMPCO ' 83 for their dedicated efforts in putting together a stimulating program and an enjoyable social agenda, all of which was planned and executed in a most thorough and satisfactory manner.

Carried with standing ovation President Cayford then expressed the sincere appreciation and thanks that the Institute owes committee chairman P.G. Gilbert and his committee for their fine work.
14.

\subsection{Forestry Constituency}

President Cayford reported on progress noting the formation of the Canadian Federation of Professional Foresters Association at Prince George in 1982 and the Forestry Constituency meetings that have been sponsored jointly by CFA and CIF both at Prince George and Sault Ste. Marie.

14.2 Canadian Journal of Forest Research

Editor of the Journal, Dr. Bruce Dancik, gave a short report and expressed appreciation to associate editors and reviewers. J.H.G. Smith suggested that a title list of CJFR articles be published in the Forestry Chronicle.

14.3 The Royal Commission on the Economic Union and Development Prospects for Canada (Macdonald Commission) Dr. Paillé reported on steps being taken to submit a CIF brief to the commission.

\subsection{National Forestry Week}

D.A. Hall drew delegates attention to this event scheduled for May $6-12,1984$. The theme will be "Tomorrow's Forest, Today's Challenge".

15. Introduction of New Officers

President Cayford expressed the Institute's appreciation to Past President Garner and then welcomed the new 2nd Vice-President J.W. Toovey to the platform. President Cayford thanked the Executive and all members for their support during $1982 / 83$ and in passing the gavel to his successor $\mathrm{Dr}$. Gilbert Paillé he expressed his full confidence in the new President. President Paillé then took the chair. $\mathrm{He}$ spoke of his plans for 1983-84 and his appreciation to Past President Cayford. This was followed by prolonged applause.

16. MOTION G83-12 (J.A. Kayll, P.J.B. Duffy) THAT the 75th Annual Meeting stand adjourned.

Carried 


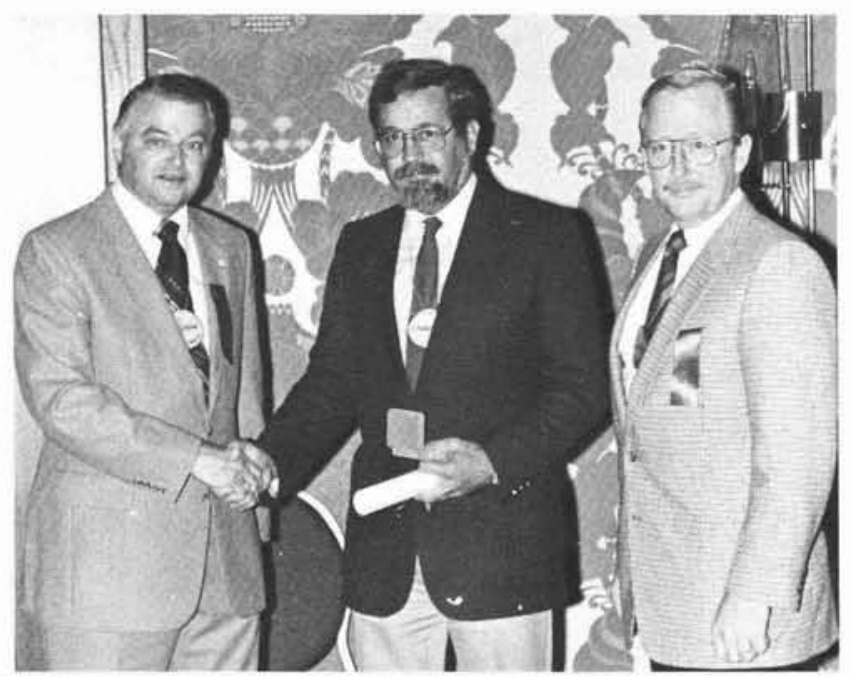

Andre Fortin is presented with the Canadian Forestry Scientific Achievement Award by president James Caytord, while incoming President Gilbert Paillé looks on.

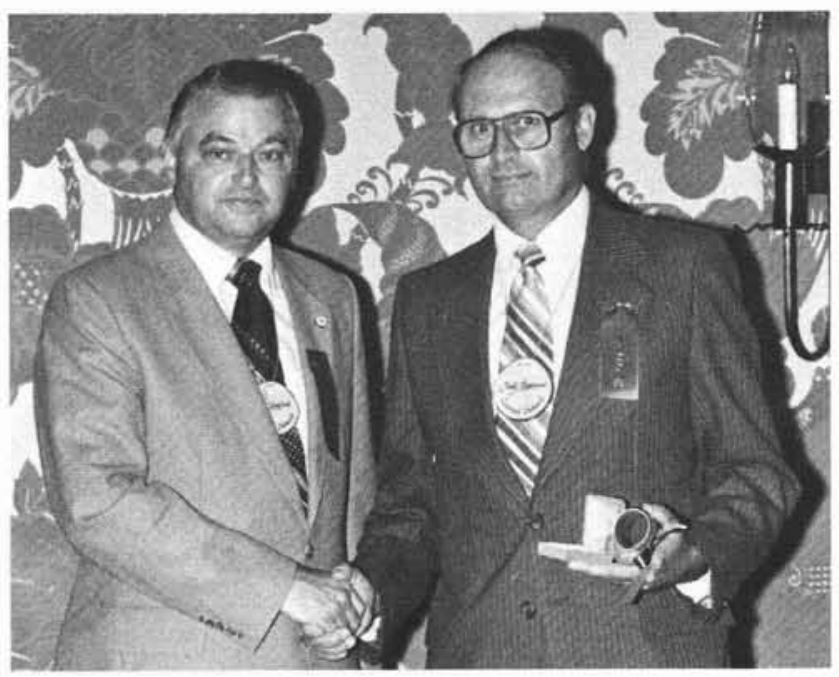

Jack Basham is presented with the Canadian Forestry Scientific Achievement Award by President James Cayford.

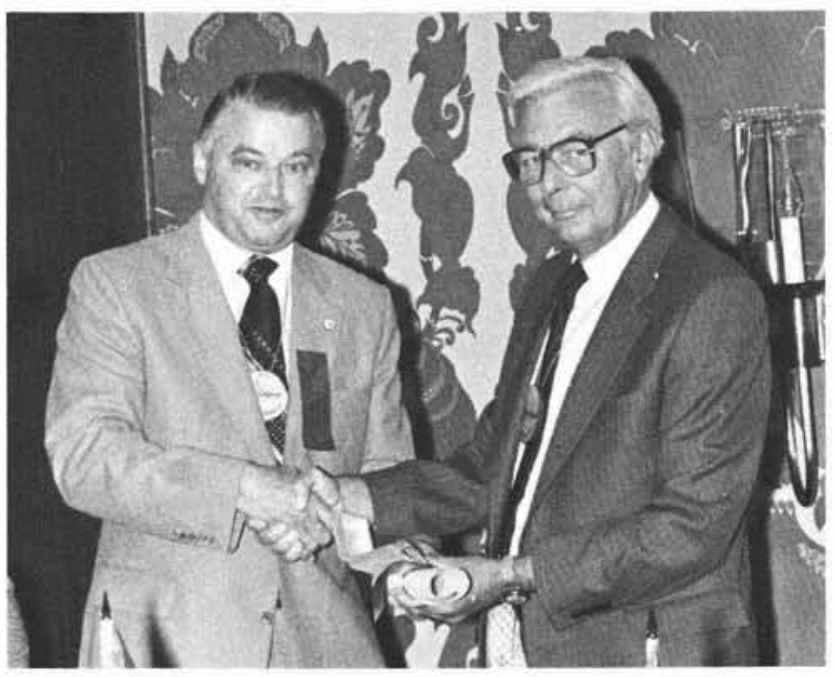

Duncan Naysmith is presented with the Canadian Forestry Achievement Award by President James Cayford. 


\section{Fellow Membership/ Membres Émérites}

\author{
Alfred Kabzems
}

\begin{abstract}
Alfred Kabzems is his own man - a forester's forester. He speaks his mind, and always with the best interests of the forest at heart, has confronted both industry and government on issues of importance. Alfred is the forester we all hope one day to become.
\end{abstract}

Alfred was born June 20,1911 in Latvia. After elementary and secondary schooling, he graduated from the University of Riga and Agricultural Academy of Jelgava, Latvia with a Forest Engineer degree in 1943. He served in the Latvian merchant marine and Latvian army during 1931-33. Prior to and after graduation, Alfred worked for almost ten years in different factories and sawmills of Latvian Wood Ltd. Timber Company, Riga; first as an apprentice scaler, Production Manager, and later as Manager of the Company's sawmill and box factory in Libau, Latvia.

The late war years were spent as a forced labourer in a box factory in Czecholslovakia. After the war, Alf supervised two circular sawmills of the British North German Timber Control in Lower-Saxony, Germany until August 1947.

In August 1947, Alfred came to Canada and joined the Forestry Branch of the Department of Tourism and Renewable Resources in Prince Albert, Saskatchewan. He started work there as an Assistant Forester, then as a Forester I, II, III and as Forester-in-charge of the Forest Inventory Section until his retirement in 1976 as Head of Forest Inventory.

In working with and supervising the Forest Inventory Section, Alf was involved in many diversified activities and surveys, such as: forest inventory surveys, growth and yield surveys, forest site-type and related ecological surveys. He was particularly noted for his work and guidance in the Saskatchewan ARDA program, Saskatchewan's Pilot Land Use study and the Churchill River Hydro Development Impact Study. His much under-rated and under-exposed publication "The Mixed-Wood Section in an Ecological Perspective, 1976 " deserves to be a bible for practicing foresters in Saskatchewan. Some other major publications were:

1) Ecological Land Regions, Sask. 1983. Department of Tourism and Renewable Resources, Technical Bulletin NR10.

2) Sask. Land Capability Classification for Forestry, Dept. of Natural Resources, 1972.

3) Forest Inventory, Forestry Chronicle, June 1954.

4) Some Principles of Forest Site-Type Classification, Forestry Chronicle, June 1951

On June 30, 1976 the Government of Saskatchewan presented Alf with the province's "Award for Service"

Since Alfred's retirement from the Civil Service, he has been employed as a consultant to Prince Albert Pulpwood until April 1983. Alf's field of expertise was not limited to forest management and inventory, but that his knowledge and experience in forest soils, plant ecology, and forest growth and development provided opportunities in regeneration surveys, tree planting quality checks, scarification prescriptions, thinning and tree improvement.

Alf has been an active member of the CIF from his arrival in Canada. He was Chairman of the CIF-FIC Natural Areas Committee in 1974 and 1975 . He is member of the National(CIF) Ecoregions Working Group. Alf is also an Honorary Life Member of the Saskatchewan Forestry Association and a member of the Latvin Forestry Society.

Alfred Kabzems has been a leader in the natural area and ecological reserves work in the province of Saskatchewan. This man is to be admired for his knowledge - a true forest ecologist - and respected for his accomplishments. Alfred epitomizes all that is good in forestry and is worthy of recognition.

\section{Canadian Forestry Achievement Award 1983 Duncan Naysmith}

The Canadian Institute of Forestry is proud to recognize and acknowledge the outstanding achievement of a Canadian forestry leader, Mr. Duncan Naysmith.

Duncan Naysmith has devoted his professional life to the advancement of forestry, with his major goal being the routine practice of forest management by the forest industry.

After graduation from the University of Toronto in 1946 , Duncan started work with Abitibi Power \& Paper at Sault Ste. Marie where he was involved in planning a comprehensive forest inventory using aerial photography. In 1949 he transferred to the Pine Falls Division in Manitoba where he became Divisional Forester in 1952. He returned to Sault Ste. Marie in 1955 and in 1964 was promoted to the Toronto Office as Assistant Manager of Forestry and Resource Planning. In 1971 he became Manager. This broad exposure to forestry conditions across Ontario and Manitoba gave him an understanding of the demands that would be placed on Canadian and Ontario forests in the 1970's and 1980's. He recognized the possibility of wood shortages and in 1975 was successful in having his company focus on the growth potential of its own lands. The result was a developing interest on the part of Abitibi-Price in its freehold and the potential to grow more fibre to permit future plant expansion.

Working cooperatively with the Ontario Forest Industries Association members and the Ontario Ministry of Natural Resources, he assisted in the development of Forest Management Agreement (FMA) philosophy and procedures. His efforts within his Company resulted in Abitibi-Price signing the first FMA in Ontario in 1979.

Duncan, by his unwaivering determination to reach his goal, has been a key figure in achieving acceptance of FMA's by industry and in bringing them into reality. To date, Abitibi-Price has signed three FMA's. Having the vehicle, he set out with enthusiasm, ensuring that within his own Company, FMA's were a workable means of achieving forest renewal. The proof of his success is the 1983 planting of approximately 10000000 trees on Abitibi-Price's Ontario limits. Additionally, through his efforts, Abitibi-Price has signed a forest management license in Manitoba.

Duncan has been active for many years with the Ontario Forest Industries Association. He served for a number of years as Chairman of the Forest Management and Roads Committee. He addressed issues in a determined and conscientious manner during those years where he proved a quiet but effective counsellor in presenting the industry viewpoint to government.

Duncan has been active in the Canadian Pulp and Paper Association and in 1950 was recipient of the J.A. Bothwell Award for Meritorious Achievement in Forest Conservation. $\mathrm{He}$ has been a member of the Ontario Professional Foresters Association, the Canadian Institute of Forestry, and a Past President and Director of the Ontario Forestry Association. He also served on a Canadian Industry Committee of FAO for two years documenting world solid wood production. 
Duncan Naysmith personifies the patient, persistent and effective professional who has maintained a high level of credibility with both the public and his peers throughout a long and productive career. He is a worthy recipient of the Canadian Forestry Achievement Award.

\title{
Canadian Forestry Scientific Achievement Award 1983
}

\author{
Dr. J.T. Basham
}

The Canadian Institute of Forestry takes pride in presenting the Canadian Forestry Scientific Achievement Award to Dr. Jack T. Basham.

Dr. Basham has been associated with the development of forest pathology as a science in Canada, almost since its inception. His research in stem decays in living trees elucidating cull and various associated stand characteristics for Ontario tree species are classics both in terms of practical application to forestry in eastern Canada and to the scientific understanding of this class of disease. His reputation has grown steadily and persistently since he began decay research in 1948 and today he is the best known and most eminent forest pathologist in Canada.

The results of his decay research have led to more accurate tree inventory data in Ontario, to adjustments in scaling regulations and stumpage rates, to a better basis for planning allowable cuts and for estimating net merchantable tree volumes.

His more than 47 excellent refereed publications in the most reputable scientific journals and their continual citation in texts and research papers around the world, attest to his scientific abilities.

Dr. Basham's research has resulted in a much deeper knowledge of decay incidence and relationships, and of the identity and relative importance of the numerous fungi responsible for stem decay of trees, both living and dead. When he started his research on tree decay it was accepted that dead branches and branch stubs were the most common, if not the only, avenue of entrance for stem decay fungi in living trees. He demonstrated that in most tree species, stem wounds are more important than dead branches as points of entry for decay fungi, a very important principle when working out control procedures through silvicultural manipulations.

Throughout his career Dr. Basham has had contacts with the forest industry in Ontario concerning the application and integration of his research results in their forest management plans. This aspect of his work has more recently been extended to the Atlantic Provinces, where he has advised representatives of both industry and provincial governments in New Brunswick, Nova Scotia and Newfoundland of potential problems and solutions to these problems, in salvaging stands of balsam fir and spruce which are being killed by the spruce budworm over millions of hectares.

Dr. Basham was born in Lachine, Quebec, in 1926. He received his $B S c$ in Forestry at the University of Toronto in 1948 and MA at the same university in 1950. He earned his PhD at Queen's University in 1958. In 1945 at the University of Toronto Dr. Basham was awarded the White Pine Bureau Scholarship for highest standing in first year forestry. In 1946 and 1947 he received the Leonard Foundation Scholarship for general proficiency. In 1947 he also received the F.K. Morrow Forestry Scholarship for highest standing in third year forestry at that university.

His career in tree disease research began in May, 1948 as a technical officer with the Department of Agriculture at Maple, Ontario. With the closing of the Forest Pathology Laboratory at Maple, Dr. Basham moved to Sault Ste. Marie in 1968 where he currently continues his pathology research at the Great Lakes Forest Research Centre. He has held memberships in the American Phytopathological Society, Canadian Phytopathological Society, Ecological Society of America, Canadian Institute of Forestry, Canadian Botanical Association, and the Ontario Professional Foresters Association. In 1980 he was appointed to the newly established Committee on Forest Pathology in the International Society of Plant Pathology. $\mathrm{He}$ is associate editor (pathology) of The Forestry Chronicle.

The Canadian Institute of Forestry congratulates this eminent scientist for his untiring and incisive contributions on tree decay. His outstanding devotion has greatly improved our knowledge in an area essential to successful forest management in Canada. 


\section{Canadian Forestry Scientific Achievement Award 1983}

\author{
Dr. J.A. Fortin
}

$\mathrm{He}$ is one of the first Canadians to study the symbiotic relations between soil-borne microorganisms and higher plants. His interest in the subject led him to undertake fundamental research which resulted in the formation of a high caliber team of researchers and graduate students. The results of this fundamental research were applied to the reforestation of large barren and unstable man-made sites such as those created by the Manic V hydro electric power development. As a matter of fact, the technique of industrial scale reforestation with alder inoculated with Frankia (a Nitrogen fixing actinomycete) is now effective and operational.

In recent years, much of his research effort has centred around a type of plant symbiosis called "vesicular-arbuscular endomycorrhiza". This type of symbiosis involves approximately $95 \%$ of all vascular plants, giving them better access to nutrients with low mobility such as phosphorus, zinc and copper. The application of this research to apple tree cultivation is full of promise. Experimentation with the same selected symbiotic type on Fraxinus americana (Ash) is already conclusive. In addition, research is underway on endomycorrhizae of pines.

The significance of this research on forestry is clear:

- The Montreal botanical gardens started this year the production of super maples inhabited by mycorrhizal fungi.

- A company, marketing endomycorrhizae for domestic uses, is now operational.

- The Quebec Ministry of Energy and Resources is studying the possibility of producing large scale reforestation stock inoculated with mycorrhizal fungi.

As you can see, Dr. Fortin is a man of vision. He has foreseen the immense potential of his research well before biotechnology, to which his research is related, acquired the prominence it has today.

Dr. Fortin has in the pursuit of his research published over 60 scientific papers and reports. He has supervised 15 masters and doctorate theses, and is presently directing 8 graduate students. His administrative responsibilities in various committees and associations are numerous.

J. André Fortin was born in Québec in 1937. He received a BSc in biology in 1962 from Laval University, a MSc in botany in 1964 from Wisconsin University, and a DSc in forest biology in 1966 from Laval University. He worked at the Pasteur Institute in 1967 to complete his knowledge in soil microbiology.

Dr. Fortin has been teaching at Laval University since 1962 $\mathrm{He}$ is presently a professor in the Department of Ecology and Pedology. Mycology, vegetal symbiosis and soil biology are his teaching fields.

It is not the first honorific award that $\mathrm{J}$. André Fortin has received. He was awarded the Léo Parizeau prize from ACFAS and the René Pomerleau medal in 1982; while in 1983, he was elected to the Royal Society of Canada.

Today, the Canadian Institute of Forestry recognizes his exceptional research on endomycorrhizae. We firmly believe that he will continue his distinguished career as a scientist. and we wish him good luck.

\section{Réalisation scientifique exceptionnelle dans le domaine de la Foresterie au Canada}

\author{
Dr J.A. Fortin
}

L'Institut Forestier du Canada est heureux de présenter le prix pour une réalisation scientifique exceptionnelle dans le domaine de la foresterie au Canada au Dr J.A. Fortin.

Le lauréat fut parmi les premiers canadiens à se pencher sur les relations de symbiose existant entre les microorganismes du sol et les plantes supérieures. Son intérêt pour le sujet l'a amené à entreprendre des recherches fondamentales, lesquelles ont débouché sur la création d'une équipe de chercheurs et d'étudiants gradués de haut calibre. Sur la lancée, il a appliqué le résultat de ses recherches fondamentales au reboisement des sites de grands travaux dont la Manic V. En effet, la technique de culture à grande échelle de l'aulne crispé associé à l'actinomycète FRANKIA, (fixateur d'azote) est au point et opérationnelle.

Ces dernières années il s'est penché sur le problème des endomycorhizes à vésicules et arbuscules. Ces symbiotes sont impliqués dans environ $95 \%$ des plantes vasculaires et leur assurent un meilleur accès aux éléments nutritifs peu mobiles tels que le phosphore, le zinc et le cuivre. Déjà, l'application des recherches à la culture du pommier semble prometteuse. L'expérimentation des mêmes symbiotes sélectionnés sur le Fraxinus americana est déjà concluante. De plus, des recherches sont en cours sur les endomycorhizes des pins.

La signification de l'ensemble de ces recherches sur le milieu forestier est déjà manifeste:

- Le jardin Botanique de Montréal commence à produire dès cette année des érables mycorhizés

- Une compagnie "Biotertec Inc." est en activité; elle commercialise les endomycorhizes pour fins domestiques.

- Le M.E.R.Q. étudie la possibilité de produire les semis mycorhizés à grande échelle.

Notre lauréat est donc un homme de vision qui a su entrevoir le potentiel immense de sa voie de recherche longtemps avant que la biotechnologie, à laquelle ses travaux se rattachent, n'acquière l'importance qu'on lui connaît aujourd'hui.

En plus de s'occuper de sa recherche, le Dr Fortin a publié plus de 60 articles scientifiques et rapports; il a dirigé une quinzaine de thèses de maitrise et de doctorat et en dirige présentement huit. Ses responsabilités administratives au sein de divers comités et associations sont nombreuses.

J. André Fortin est né à Québec en 1937. II a obtenu un B.Sc. en biologie en 1962 de l'Université Laval, un M.Sc. en botanique en 1964 de l'Université du Wisconsin, et un D.Sc. en biologie forestière en 1966 de l'Université Laval. II a fait un stage à l'Institut Pasteur en 1967 pour parfaire ses connaissances en microbiologie du sol.

Le Dr Fortin enseigne à I'Université Laval depuis 1962. II est présentement professeur titulaire au Département d'Ecologie et de pédologie de la Faculté de Foresterie et Géodésie. La mycologie, les symbioses végétales et la biologie du sol sont les matières qu'il enseigne.

Cen'est pas la première distinction honorifique que reçoit $\mathrm{J}$. André Fortin. II a reçu le prix Léo Parizeau de l'ACFAS et la médaille René Pomerleau en 1982; tandis qu'en 1983, il a été élu à la Société Royale du Canada.

Aujourd'hui c'est au tour de l'Institut Forestier du Canada de le féliciter pour ses recherches de qualité exceptionnelle sur les endomycorhizes. Nous sommes convaincus qu'il va continuer à se distinguer et nous lui souhaitons bonne chance. 